\title{
El abogado ante las causas matrimoniales canónicas. Ciertas cuestiones deontológicas
}

The Lawyer in Canonical Marriage Causes. Some Ethical Issues

José María MARTí SÁNCHEZ

Profesor Titular de Derecho Eclesiástico del Estado

Universidad de Castilla-La Mancha. Albacete orcid 0000-0002-0408-7946

josemaria.marti@uclm.es
Resumen: La participación del abogado en el foro canónico es relevante. Debe cumplir con unos requisitos deontológicos que garanticen su concurso al fin institucional del proceso (la verdad del matrimonio y su relación con la unión concreta). Es básica la lealtad hacia todo ello. Se destaca la tensión entre publicidad procesal y protección de la intimidad.

Palabras clave: Abogado-canonista, Deontología, Nulidad matrimonial.
Abstract: Lawyers play an important role in the canonical process; so they ought to meet established ethical standards ensuring their commitment to the institutional purpose of the process (the truth of marriage, in the specific case). Such loyal commitment to the process is fundamental. In particular, the tension between the public dimension of the process and the need to respect personal privacy is explored here.

Keywords: Canon-Lawyer, Professional Ethics, Marriage Annulment. 


\section{INTRODUCCIÓN}

I preocupación por el matrimonio y los recientes documentos eclesiales que lo estudian incitan a formar a profesionales que atiendan a los fieles, en este campo. También la preparación es necesaria, desde el punto de vista jurídico. La Exhortación Apostólica Amoris Laetitia (2016) reproduce unas palabras de la Relación final del Sínodo de los Obispos de 2015. Éste es el pasaje: «la aplicación de estos documentos [se refiere a los "motu proprio" que revisan el procedimiento canónico matrimonial] es una gran responsabilidad para los Ordinarios diocesanos, llamados a juzgar ellos mismos algunas causas y a garantizar, en todos los modos, un acceso más fácil de los fieles a la justicia. Esto implica la preparación de un número suficiente de personal, integrado por clérigos y laicos, que se dedique de modo prioritario a este servicio eclesial» (n. 244).

Concretamente, el citado Motu Proprio Mitis Iudex da nueva redacción al c. 1673 del Codex Iuris Canonici y facilita la participación de los laicos, en los tribunales eclesiásticos: $\ll \$ 3$. Las causas de nulidad de matrimonio se reservan a un colegio de tres jueces. Éste debe ser presidido por un juez clérigo, los demás jueces pueden ser también laicos». Previo a esto, en las Reglas de procedimiento para tratar las causas de nulidad de matrimonio, se menciona la investigación prejudicial o pastoral acerca de «los fieles separados o divorciados que dudan sobre la validez del propio matrimonio o están convencidos de su nulidad» (art. 2) y que «se orienta a conocer su condición y a recoger elementos útiles para la eventual celebración del proceso judicial, ordinario o más breve». La investigación será confiada, por el Ordinario del lugar, a personas consideradas idóneas, dotadas de competencias no sólo exclusivamente jurídicocanónicas. Si citan, luego, al párroco propio o el que ha preparado a los cónyuges para la celebración de las nupcias, y «a otros clérigos, consagrados o laicos aprobados por el Ordinario de lugar» (art. 3).

En estas páginas recordamos la disposición que se requiere del personal canónico que se desenvuelve en el ámbito forense, principalmente del abogado. Es la premisa para dar cumplimiento al encargo del cliente y a la confianza de la Iglesia que lo admite en el ámbito de su jurisdicción.

La deontología es la condición para un ejercicio ordenado del oficio de abogado. Las normas deontológicas que fueron inicialmente consuetudinarias luego, con la codificación, se han explicitado en las fuentes legales. Frente a los códigos deontológicos de los colegios de abogados civiles, faltan textos es- 
pecíficos para el abogado canonista. La Instrucción Dignitas connubii (2005) recoge de modo más o menos detallado diversas exigencias, así como medidas disciplinarias o sancionadoras. Es una base muy importante para abordar la cuestión.

La deontología del abogado se ha enriquecido, en la actualidad, gracias a las reformas normativas y mejoras técnicas (exempli causa, ya no sólo interesa la pertinencia y diligencia en la aportación de la prueba, la citada instrucción se preocupa también de que se obtenga por una vía legítima). Asimismo, influye el reto que supone la deriva de los Ordenamientos nacionales y supranacionales. En materia matrimonial, se constata una falta de referencias, un deterioro de la norma y más aún de su capacidad ordenadora, dado el individualismo del hombre contemporáneo (desheredado y desarraigado). Hoy predomina el vitalismo, sobre cualquier institución, en la estima social y política. Otro elemento perturbador, asociado al relativismo, es el positivismo que tiene amplio cauce en los Ordenamientos contemporáneos.

En este trabajo interesa estudiar cuatro cosas: $1^{\text {a }}$ ) la figura del abogado, dada la especificidad de las causas matrimoniales canónicas; $2^{\mathrm{a}}$ ) el objetivo institucional del proceso canónico, o modo de cohonestar interés de parte y búsqueda de la verdad sobre la unión; $3^{\text {a }}$ ) cuándo se debe interponer una causa de nulidad matrimonial, y $4^{\mathrm{a}}$ ) cómo actuar, sobre todo por parte del abogado, ante los datos sensibles que afloren a lo largo del proceso. Vamos a desarrollarlos por el mismo orden de su enunciación.

Hemos procurado actualizar las referencias legales a las últimas reformas y disposiciones. Sin embargo, es inevitable que las citas u obras consultadas, anteriores a 2015 (M.P. Mitis Iudex) o incluso a 2005 (Instrucción Dignitas connubii), no se acomoden al estado actual de la disciplina matrimonial canónica. Desde 1983, los cambios se han producido predominantemente en el terreno procedimental.

\section{Deontología específica DEL ABogado CANONISTA}

Por deontología entendemos la ciencia y el arte del ejercicio profesional que cuida de que, más allá de que se haga justicia al cliente o patrocinado, en el fallo del pleito o contencioso, la relación con aquél y con la Administración de Justicia se ajuste a lo que les es debido. El sentido de justicia envolvería todo el ámbito del ejercicio profesional del abogado, en su rico horizonte. Por 
otro lado, en cuanto que su conducta afecta a un orden o corporación profesional también es muy relevante que el abogado canonista respete los principios que lo rigen, así como las relaciones entre sus miembros ${ }^{1}$.

Los procesos matrimoniales exigen, por la hondura y trascendencia de lo que se ventila (causas relativas al bien público y al estado de las personas), una mirada vigilante que garantice siempre la dignidad de quienes intervienen (partes, ministros del tribunal, testigos, etc.) ${ }^{2}$. Además supone un mayor compromiso con que el resultado final sea justo. La diligencia, la delicadeza y la rectitud moral nunca deberían faltar en la materia. Llobell afirma que: «soltanto nella misura in cui la parte [...] sia convinta di essere stata difesa dal suo patrono con tutti i mezzi leciti possibili, la sentenza potrà disporre definitivamente sulla controversia e riuscire ad ottenere l' "interno" assenso della parte» ${ }^{3}$. La jurisdicción canónica debería aspirar a conseguir la paz exterior (comunitaria) e interior (del alma). Las pautas que aquí se apunten no se atendrán a una deontología de mínimos, poco acorde con el foro canónico, sino que aspirarán a la excelencia que se inspira en lo mejor y lo posible. La profesión de abogado canonista debería vivirse como una vocación de servicio humilde a la verdad $^{4}$.

La verdad tiene, en el ámbito forense, un doble alcance. De un lado se refiere a la verdad doctrinal que afecta al matrimonio (institución), de otra, a la averiguación de los hechos que se refieren a la verdad histórica de la unión concreta $^{5}$. La justicia no deja de ser la plasmación de la verdad en lo que se refiere a las relaciones humanas. La justicia debe estar atenta a la realidad de los hechos, que actúa de presupuesto a las previsiones normativas. Asimismo, la

${ }^{1}$ S. SCAGLIA, Notazioni per una deontologia sistematica dell'Avvocato canonista, 1-2 (http://bibliotecanonica.net/docsao/btcaod.pdf [consulta: 19 mayo 2016]).

2 C. DE Diego-Lora, Criterios morales de la actuación de abogados y peritos en las causas matrimoniales, Ius Canonicum 41 (2001) 234-235.

3 J. LlOBELL, Il patrocinio forense e la «concezione istituzionale» del processo canonico, en A. BONNET C. Gullo (a cura di), Il processo matrimoniale canonico, $2^{\mathrm{a}}$ ed., Città del Vaticano, 1994, 439-478 (http://didattica.pusc.it/pluginfile.php/6578/mod_page/content/9/021AVVOC.DOC [consulta: 19 mayo 2016], 17).

${ }^{4}$ C. M. Morán Bustos, Criterios de actuación de los miembros del tribunal y los abogados en el desarrollo del proceso de nulidad, en AA.Vv., Procesos matrimoniales canónicos, Asociación española de canonistas, Dykinson, Madrid 2014, 102-108 y 113.

5 P. BIANCHI, Lidentità dei ruoli nella deontologia forense della Chiesa (testo provvisorio), Pontificia Università della Santa Croce, Programma di formazione permanente per operatori dei tribunali ecclesiastici, V Corso di aggiornamento in diritto matrimoniale e processuale canonico, 19 settembre 2013 (http://www.pusc.it/sites/default/files/can/cagg13/doc/130919_Bianchi.pdf [consulta: 19 mayo 2016] 3-4). 
justicia debe profundizar en la configuración de las instituciones jurídicas y su adecuación al ser del hombre ${ }^{6}$.

En la historia, el Derecho procesal se ha ido perfeccionando para hacerse más dúctil a los propósitos de búsqueda de la verdad Racionalidad, esclarecimiento de los hechos e integridad, especialmente del juez ${ }^{7}$.

\subsection{La jurisdicción civil y la canónica}

El espíritu de las causas canónicas no se confunde con el de las que se interponen en el foro civil, donde predomina lo funcional o pragmático. El juez civil excluye expresamente una visión panorámica acerca del matrimonio y de los cónyuges, para focalizar su atención en lo relevante para el fin establecido por la ley civil (separación o divorcio, principalmente) ${ }^{8}$. En buena medida, se desentiende de la verdad sustancial, subyacente a la pretensión?

Las jurisdicciones también difieren en que, en sede canónica, el vínculo no es disponible por las partes. El proceso sólo dilucida si existe vínculo, porque se constituyó válidamente, o era sólo aparencial. El contencioso se produce siempre, mas no tiene por qué enfrentar a los cónyuges. Propiamente se formaliza con el defensor del vínculo (c. 1432), figura inexistente en la esfera civil. Es más, la reforma del procedimiento de nulidad matrimonial de 2015 alienta el acuerdo entre las partes, de cara a beneficiarse de un procedimiento «más breve», resuelto por el Obispo ${ }^{10}$. Antes ya se contemplaba la posibilidad de que las partes fuesen defendidas por un solo abogado ${ }^{11}$. Es una hipótesis que suscita problemas técnicos, por ejemplo, a la hora de articular la sustentación objetiva de la causa y su instrucción, piénsese en la declaración-confesión

${ }^{6}$ C. J. ERRÁzURIz M., Sul rapporto tra diriito e giustizia: valore e aitualita delia tradizione ciassica e cristiana, Persona y Derecho 40 (1999) 337-342.

7 F. MARTíneZ MARTÍNEZ, El proceso canónico y la verdad, en Aa.Vv., Religión, matrimonio y Derecho ante el s. XXI. Estudios en homenaje al Prof. R. Navarro-Valls, vol. II, Iustel, Madrid 2013, 2991-3013.

8 F. GIL Delgado, Lo peculiar del procedimiento declarativo de nulidad del matrimonio, en J. Bogarín

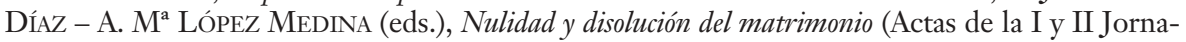
das de Derecho matrimonial canónico de la Universidad de Huelva), Publicaciones de la obra social y cultural CajaSur, Córdoba 2007, 47-48.

9 E. DE LEÓN REY, Publicación de las actas, privacidad de los hechos y pruebas secretas (c. 1958.1 CIC 83 / art. 230 DC), en Aa.Vv., Procesos matrimoniales canónicos..., cit., 161-162.

${ }^{10}$ C. 1683 . «Al mismo Obispo compete juzgar las causas de nulidad cada vez que: $1^{\circ}$ la petición haya sido propuesta por ambos cónyuges o por uno de ellos, con el consentimiento del otro [...]».

11 La Instrucción Dignitas connubii preveía, por primera vez, la posibilidad de que: «Si ambos cónyuges piden la declaración de nulidad del matrimonio pueden nombrar un procurador o abogado en común» (art. 102). 
de las partes, y deontológicos: ¿cómo se actúa cuando uno de los cónyuges revoca unilateralmente el mandato al abogado? ${ }^{12}$

Hay otro aspecto que no podemos eludir. Mientras en la jurisdicción civil el matrimonio se ha desdibujado y ha decaído en su relevancia ${ }^{13}$, el Derecho canónico mantiene su apuesta por él: «Es preciso redescubrir la verdad, la bondad y la belleza de la institución matrimonial, que siendo obra del mismo Dios a través de la naturaleza humana y de la libertad del consentimiento de los cónyuges, permanece como realidad personal indisoluble, como vínculo de justicia y de amor, ligado para siempre al proyecto salvífico y elevado en la plenitud de los tiempos a la dignidad de sacramento cristiano. ¡Ésta es la realidad que la Iglesia y el mundo deben promover!» (Alocución de Juan Pablo II a la Rota Romana, 2004).

La Alocución de Juan Pablo II a la Rota Romana de 28 de enero de 2002 es ilustrativa, para conocer el contraste entre el modo de concebir las causas matrimoniales, en el foro canónico y el civil. Apunta a una posible contaminación que desnaturalizaría la especificidad canónica y los valores que la sostienen. «Cuando se considera la función del derecho en las crisis matrimoniales, con demasiada frecuencia se piensa casi exclusivamente en los procesos que sancionan la nulidad matrimonial o la disolución del vínculo. Esta mentalidad se extiende a veces también al derecho canónico, que aparece así como el camino para encontrar soluciones de conciencia a los problemas matrimoniales de los fieles». Sin negar este efecto, se advierte de que la eficacia se supedita a la salvaguarda de la indisolubilidad del vínculo, cuando resulte contraído válidamente. «Más aún, la actitud de la Iglesia es favorable a convalidar, si es posible, los matrimonios nulos (cfr. Código de Derecho Canónico, c. 1676; Código de Cánones de las Iglesias orientales, c. 1362). Es verdad que la declaración de nulidad matrimonial, según la verdad adquirida a través del proceso legítimo, devuelve la paz a las conciencias, pero esa declaración -y lo mismo vale para la disolución del matrimonio rato y no consumado y para el privilegio de la fe- debe presentarse y actuarse en un ámbito eclesial profun-

12 C. M. Morán Bustos, Criterios de actuación..., cit., 72-73. Para la última hipótesis, los códigos deontológicos civiles imponen la renuncia a la defensa de ambos, salvo autorización expresa de ellos, para continuar con el otro cónyuge.

13 Entre muchos, A. BERNÁRDEZ CANTÓN, Elementos definidores del matrimonio implícitos en las causas de nulidad y separación, en J. BOGARÍN DíAZ - A. Ma LóPEZ MEDINA (eds.), Nulidad y disolución del matrimonio..., cit., 21-22; y J. Ma MARTÍ SÁNCHEZ, Matrimonio, tradición religiosa y concordataria, en J. Ma MarTí SÁNCHEZ - M. Moreno Mozos (coords.), Matrimonio religioso y Derecho español concordado, Comares, Granada 2016, 26 y ss. 
damente a favor del matrimonio indisoluble y de la familia fundada en él» (párr. $6^{\circ}$ ).

\subsection{Quién puede ser abogado en una causa canónica y qué disposición debe moverle}

Aquí procuramos analizar lo más característico de los procedimientos canónicos. Recordemos el objetivo final de todo el Derecho canónico y con él de la acción de la Iglesia. Dice el c. 1752, como colofón del código, que: «la salvación de las almas» «debe ser siempre la ley suprema en la Iglesia» ${ }^{14}$. Por ello vela la selección de los patronos en las causas canónicas ${ }^{15}:$ :El procurador y el abogado han de ser mayores de edad y de buena fama; además, el abogado debe ser católico, a no ser que el Obispo diocesano permita otra cosa, y doctor, o, al menos, verdaderamente perito en derecho canónico, y contar con la aprobación del mismo Obispo». El requisito de la pertenencia a la Iglesia, no es sólo un dato externo. Implica también una actitud personal, una orientación vital al seguimiento de Cristo, que deja su impronta en el patrocinio y defensa de la parte, en el proceso ${ }^{16}$. La pericia no equivale a una titulación académica específica, pero sí a un control de la técnica jurídico-canónica. Actuar con ciencia y conciencia, por parte de los operadores jurídicos, es una norma básica que está relacionada con la debida preparación y la mejor disposición ${ }^{17}$. «La competenza tecnica è garanzia per esercitare con indipendenza e autonomia le facoltà di difesa che esige il caso. Da qui il dovere di non accettare quei casi per cui l'avvocato non si considera all'altezza» ${ }^{18}$. Scaglia habla de un principio deontológico fundamental, sólo supeditado al de la confianza, que sería el de corrección, en todos los órdenes de actuación del abogado ${ }^{19}$.

${ }^{14}$ Ya apuntado en la Alocución a la Rota de 1944. Ver: E. DE LEÓN ReY, Publicación de las actas..., cit., 158-161.

15 C. 1483 . Ver el comentario de M. A. Cremades Romero, Dimensión pastoral de la administración de justicia en la Iglesia (separata), Clausura del Curso de Actualización Canónica para Abogados 2003-2004, Tribunal Eclesiástico, Diócesis de Albacete (22 de junio de 2004) 18-20; y C. DE DiEGO-LORA, Criterios morales..., cit., 233-246.

${ }^{16}$ S. SCAGLia, Notazioni per una deontología..., cit., 6-7.

${ }^{17}$ C. M. Morán Bustos, Criterios de actuación..., cit., 54-56.

${ }_{18}$ M. J. Arroba Conde, Deontologia e norme processuali, en Aa.Vv., Deontologia degli operatori di tribunali ecclesiastici, Libreria Editrice Vaticana, Città del Vaticano 2011, 75-78 (http://www.pul.it/ wp-content/uploads/2011/10/MaterialeDidattico-per-il-Tema-26.pdf [consulta: 8 mayo 2016]).

19 S. SCAGLiA, Notazioni per una deontología..., cit., 10-11, en relación con el c. 128 y el art. 111.3 de la Dignitas connubii. 
La Dignitas connubii exceptúa del requisito de la aprobación del Obispo a quienes han obtenido el título de Abogado Rotal, «pero el Obispo Moderador puede prohibirles por causa grave el ejercicio del patrocinio en su tribunal; en tal caso cabe recurso a la Signatura Apostólica» (art. $105 \$ 2$ ). La aprobación del Obispo hace las veces de la inscripción en la corporación profesional, necesaria para el Ordenamiento español. Otorga la condición de abogado eclesiástico y el compromiso de ejercer el oficio dentro de su estatuto canónico disciplinar ${ }^{20}$. Un aspecto central de la relación dentro y fuera del tribunal, con el cliente, las otras partes, el personal de justicia, y demás profesionales y colaboradores es «mantener y respetar la dignidad y lealtad profesional» ${ }^{21}$.

Llobell señala que es conveniente que el abogado, además de conocer las peculiaridades del Derecho canónico, «a causa della dimensione sociale extra ecclesiale del matrimonio canonico e delle ripercussioni che un'eventuale dichiarazione di nullità può avere presso l'ordinamento statuale», esté también legitimado, para actuar en el foro civil ${ }^{22}$.

Completa la disposición codicial (c. 1483) la Dignitas connubii. Su art. 111 vela por la efectividad del citado canon. Dice así: «\$1. Los abogados y procuradores que cometan delitos contra el encargo a ellos encomendado, deben ser castigados conforme a derecho (cfr. cc. 1386; 1389; 1391, n. 2; $1470 \$ 2 ; 1488$ 1489). $\$ 2$. Si resulta que los mismos no están a la altura de su oficio por impericia, pérdida de la buena fama, negligencia o abuso, el Obispo Moderador del tribunal o el grupo de Obispos deben proveer adoptando las medidas adecuadas, sin excluir, si el caso lo requiere, la prohibición de ejercer el patrocinio en su tribunal» ${ }^{23}$.

La buena fama no sólo se requiere para incorporarse al elenco de patronos ordinarios u ocasionales (ad casum). Es una cualidad que ha de mantenerse, para poder desempeñar el oficio ${ }^{24}$. Consecuentemente, por esta circunstan-

${ }^{20}$ J. L. ACEBAL Luján, Abogados, procuradores y patronos ante los tribunales eclesiásticos españoles, en AA.Vv., Curso de Derecho matrimonial y procesal canónico para profesionales del foro, X, Universidad Pontificia de Salamanca, Salamanca 1992, 582.

${ }^{21}$ C. M. Morán Bustos, Criterios de actuación..., cit., 59 y 63-73.

${ }^{22}$ J. LLOBELL, Il patrocinio forense..., cit., 10.

23 En general, sobre el funcionamiento del órgano jurisdiccional, dice la Instrucción Dignitas connubii que: «Cuando la recta administración de justicia se vea impedida por negligencia, impericia o abusos, el Obispo Moderador del tribunal o el grupo de Obispos deben proveer adoptando las medidas oportunas, sin excluir, si el caso lo requiere, la remoción del oficio» (art. $75 \S 2$ ).

24 «Nel corso dell'attività forense, essi sono chiamati a mantenere siffatta integrità morale» (S. SCAGLIA, Notazioni per una deontología..., cit., 6). 
cia, por negligencia o abuso, al abogado se le podría apartar de una causa, suspenderlo o excluirlo del tribunal eclesiástico. Sobre la primera medida, dispone la Dignitas connubii que: «Tanto el procurador como el abogado pueden ser rechazados por el presidente mediante decreto motivado, bien de oficio, bien a instancia de parte, pero siempre por causa grave (cfr. c. 1487)» (art. 109).

La buena fama se extiende a su vida profesional y a la personal. Lo explica la Respuesta del Tribunal Supremo de la Signatura Apostólica (12 julio 1993, $\mathrm{n}^{\mathrm{o}}$ protocolo $24339 / 93$ ), sobre incompatibilidad para ejercer la abogacía de quienes vivan en una unión irregular o hayan intentado el matrimonio civil ${ }^{25}$. Sobre la materia se han planteado dos cuestiones complementarias. La primera, sobre cómo el abogado canonista habría de atenerse a la Doctrina Social de la Iglesia ${ }^{26}$, concretamente en el momento de fijar sus honorarios. Sería una cantidad suficiente, para su sustento familiar, acorde con los usos del foro, también civil, pero alejada del afán de lucro inmoderado y del escándalo para la Iglesia ${ }^{27}$.

La segunda duda, tiene relación con las causas de divorcio civil. ¿Debe el Abogado canonista, para mantener la «buena fama» que requiere su actuación coram Ecclesia, objetar en conciencia su intervención en los divorcios civiles? ${ }^{28}$ Así parece indicarlo el Discurso de Juan Pablo II ante el Tribunal de la Rota de 2002. Parte de una tesis: se debe evitar la cooperación con el divorcio, a pesar de su coste. «Los agentes del derecho en campo civil deben evitar implicarse personalmente en lo que conlleve una cooperación al divorcio. Para los jueces esto puede resultar difícil, ya que los ordenamientos no reconocen una objeción de conciencia para eximirlos de sentenciar» ${ }^{29}$. Luego establece una hipótesis, sería aceptable sólo si es la única vía posible para alcanzar otros efectos legítimos

${ }^{25}$ Abogados, uniones matrimoniales irregulares y causas de nulidad matrimonial. Texto y comentario de una respuesta del Tribunal Supremo de la Signatura Apostólica, Revista Española de Derecho Canónico 51 (1994) 639-645, original en: Periodica (1993) 82, 699-700.

${ }^{26}$ Las fuentes principales de ésta son: el Catecismo de la Iglesia católica y, del Consejo Pontificio de Justicia y Paz, Compendio de la Iglesia católica (2004). Como texto específico de la actuación deontológica del abogado, son reseñables «Las doce reglas morales del abogado» que formuló san Alfonso María de Ligorio (1696-1787) (http://www.filodiritto.com/articoli/2011/05/ santalfonso-maria-de-liguori-1696-1787-le-dodici-regole-morali-dellavvocato/ [consulta: 19 mayo 2016]).

27 J. LLOBELL, Il patrocinio forense..., cit., 17-18.

28 R. Ma SATORRAS FioretTI, La objeción de conciencia jurisdiccional a participar en causas de divorcio, Nulidad y disolución del matrimonio..., 107-110, y La Toga 136 (2002) 30-31; y G. CомOTTI, L'esercizio della professione nel foro civile da parte dell'avvocato ecclesiastico. Aspetti deontologici e dovere della coerenza, Quaderni di diritto ecclesiale XXIII/1 (2010) 82-84.

29 http://w2.vatican.va/content/john-paul-ii/es/speeches/2002/january/documents/hf_jp-ii_ spe_20020128_roman-rota.html (consulta: 19 mayo 2016). Ver n. 9. 
(verbigracia, evitar la violencia o vejación, la pérdida de patrimonio, etc.). Éstas son sus palabras: «Los abogados, como profesionales libres, deben declinar siempre el uso de su profesión para una finalidad contraria a la justicia, como es el divorcio; sólo pueden colaborar en una acción en este sentido cuando, en la intención del cliente, no se oriente a la ruptura del matrimonio, sino a otros efectos legítimos que sólo pueden obtenerse mediante esta vía judicial en un determinado ordenamiento (cfr. Catecismo de la Iglesia católica, n. 2383)» (ibid.).

En cuanto a la condición de católico, se justifica porque el servicio se presta en el seno de la Iglesia y sólo perteneciendo a ella se puede comprender bien lo que esto exige. Máxime cuando, como es lo más frecuente, la actividad jurisdiccional gire alrededor de un sacramento ${ }^{30}$. Se espera que los católicos desempeñen su tarea con especial solicitud y delicadeza. La Iglesia no pretende sólo resolver los conflictos y recuperar la paz. Quiere contribuir a que la convivencia y el desenvolvimiento de la sociedad natural sean más armoniosos. Pero además trata de sanarlas. Se propone reforzar y dinamizar tanto la realidad externa cuanto la interna, dimensión sobrenatural, «profonda e vitale, che unisce tutti i fedeli tra di loro e especialmente con Dio stesso ${ }^{31}$.

Consecuentemente, la Iglesia prefiere, para la recomposición del elemento humano y externo de la comunitas fidelium, la caridad a la vía judicial. Ésta no siempre hay que desecharla o reputarla como no caritativa. No existe contraposición o enfrentamiento entre justicia y caridad, sino complementariedad. La justicia (que con frecuencia requiere de la institucionalización de un tercero neutral que decida) se ve colmada, gracias al ejercicio de la caridad, esto es, del perdón ${ }^{32}$. La caridad restablece la comunión (unión de corazones), donde el Derecho no ofrece más que la concordia y el compromiso. La importancia civil del matrimonio se completa por su vertiente teológica o trascendente. El matrimonio es esencial para la realización de la Iglesia. Es fuente de gracia e instrumento de santificación.

Como tuvimos ocasión de explicar, el Obispo es el garante de que quienes actúan en juicio cumplan los requisitos deontológico-legales. La idea de

${ }^{30}$ C. M. Morán Bustos, Criterios de actuación..., cit., 77.

31 Z. Grocholewski, Aspetti teologici dell'attività giudiziaria della Chiesa, Studi Giuridici, XII. Teologia e Diritto canonico, Città del Vaticano, 1987, 198 y 204.

32 El perdón es una forma particular de amor que, según el Mensaje para la celebración de la XXXV Jornada mundial de la paz (1 enero 2002), da plenitud a la justicia humana, en cuanto que ésta es, de suyo, imperfecta: «El perdón en modo alguno se contrapone a la justicia, porque no consiste en inhibirse ante las legítimas exigencias de reparación del orden violado. El perdón tiende más bien a esa plenitud de la justicia» (n. 3). 
que se constituyan en las Diócesis elencos de patronos estables, pagados por el tribunal, es otra garantía de contar con abogados idóneos ${ }^{33}$. Fue una iniciativa que se pensó ayudaría a la formación de canonistas (laicos), en orden a poder actuar como patronos ${ }^{34}$. Sin embargo, la falta de recursos ha hecho que la previsión sea difícilmente viable. Máxime ahora que el Motu Proprio Mitis Iudex ha instado a la gratuidad de las causas matrimoniales (libres de tasas). También se duda de si esta medida podría mermar la libertad y autonomía de los abogados y, con ello, el derecho de defensa de las partes.

Sí ha prosperado la elaboración de índices o elencos de abogados admitidos en el tribunal. El propósito lo ha recogido la Dignitas connubii, con carácter imperativo ${ }^{35}$. Es un mecanismo que se ha revelado eficaz, para garantizar el patrocinio gratuito en la jurisdicción eclesiástica.

Sobre la labor del abogado, en las causas canónicas de nulidad, interesa la Alocución de Pío XII al Tribunal de la Rota Romana de 1944: «el Abogado presta a su cliente una labor de asistencia que puede extenderse a varios objetivos dentro del proceso: le asiste en la formulación de la demanda; le asiste en la recta determinación del objeto y fundamento de la controversia; le asiste indicándole las pruebas que se deben proponer, los documentos que se deben exhibir; le asiste sugiriéndole qué testimonios han de aducir en el juicio y qué puntos de la deposición testifical deben considerarse decisivos, durante el proceso; le ayuda a valorar con justeza las excepciones y argumentos del contrario en orden a refutarlos» ${ }^{36}$. El Directorio de la Pastoral Familiar para la Iglesia en España (aprobado por la LXXXI Asamblea Plenaria de la Conferencia

33 C. 1490 . «En la medida de lo posible, en todo tribunal ha de haber patronos estables, que reciban sus honorarios del mismo tribunal, y que ejerzan la función de abogado o de procurador, sobre todo en las causas matrimoniales, en favor de las partes que libremente prefieran designarlos». En la Dignitas connubii se insiste en el art. 117. «\$3. En la medida de lo posible, en todo tribunal han de nombrarse abogados estables, que reciban sus honorarios del mismo tribunal, los cuales pueden cumplir la función indicada en el $\$ 1$, y ejercen la función de abogado o de procurador de las partes que prefieran designarlos (cfr. c. 1490)».

${ }_{34}^{34}$ J. LlOBELL, Il patrocinio forense..., cit., 6.

35 Art. 112. «\$1. Al Obispo Moderador le corresponde publicar el índice o elenco en el que deben inscribirse los abogados admitidos en su tribunal y también los procuradores que suelen representar a las partes en ese tribunal. $\$ 2$. Los abogados inscritos en el elenco tienen obligación de prestar el patrocinio gratuito, por mandato del Vicario judicial, a aquellos a quienes el tribunal haya concedido este beneficio (cfr. art. 307)».

36 Discorso di Sua Santità Pio XII al Tribunale della Sacra Romana Rota, 2 ottobre 1944 (https://w2.vatican.va/content/pius-xii/it/speeches/1944/documents/hf_p-xii_spe_19441002_ roman-rota.html). Hemos reproducido la traducción que ofrece J. A. GARCÍA-CALDERÓN GARCía, La intervención del Abogado en los procesos declarativos de nulidad de matrimonio, en J. BOGARíN DíAZ - A. M ${ }^{a}$ LÓPEZ MEDINA (eds.), Nulidad y disolución del matrimonio..., cit., 61. 
Episcopal, 21 noviembre 2003) añade un matiz. También hay que informar al cónyuge del «sentido» de los procedimientos canónicos (n. 213) ${ }^{37}$.

El afán del abogado debe ser contribuir al éxito de la pretensión de su defendido, a partir de un fiel esclarecimiento de los hechos, y su correcta calificación legal. El proceso, del que es parte, se orienta a este fin último: «in tutta la sua azione non deve sottrarsi all'unico e comune scopo finale: lo scoprimento, l'accertamento, l'affermazione legale della verità, del fatto oggettivo» (mencionada Alocución a la Rota Romana de 1944). La lealtad ante el tribunal y su función de impartir justicia no supone merma de la que se le exige con su cliente ${ }^{38}$. Primero, para informarle diligentemente de la naturaleza del proceso que se inicia, su itinerario y previsible conclusión. Segundo, para una valoración de las probabilidades de éxito y los costes de aquél. La trasparencia no debe entrar en conflicto con el deber de guardar secreto o discreción sobre los datos confidenciales a que pueda tener acceso. «No se puede hacer uso de lo que se conoce en el ámbito del fuero interno, por grave que sea el hecho para resolver un problema de fuero externo (art. 194.2 Instrucción Dignitas connubii; c. 240.2 ; c. 948.2 ; c. 1548$) \gg^{39}$.

La alusión a los emolumentos es necesaria. Primero, para explorar la posibilidad de justicia gratuita, pero, de no proceder o prosperar, la minuta no puede dar lugar ni al abuso ni al escándalo. El c. 1488 vela por la ética del abogado, en este terreno ${ }^{40}$. Existe una baremación, por parte de los Colegios de

37 «Conviene que el asesoramiento jurídico sea ejercido por profesionales verdaderamente católicos que puedan explicar no sólo los procedimientos sino el sentido de los mismos, y hacer presente a la Iglesia en esa situación conflictiva».

${ }^{38} \mathrm{El}$ artículo 13 del Código deontológico de la abogacía española, aprobado por el Consejo General de la Abogacía Española en el Pleno de 27 de septiembre de 2002, y modificado en el de 10 de diciembre de 2002 (http://www.abogacia.es/wp-content/uploads/2012/06/codigo_deontologico1. pdf), regula las relaciones del abogado con sus clientes. Su apartado 9 fija los aspectos mínimos sobre los que debe informarles. También el punto 12, debe tenerse en cuenta: «La documentación recibida del cliente estará siempre a disposición del mismo, no pudiendo en ningún caso el Abogado retenerla, ni siquiera bajo pretexto de tener pendiente cobro de honorarios. No obstante podrá conservar copias de la documentación».

39 E. DE LEÓN REY, Publicación de las actas..., cit., 162.

${ }^{40}$ C. $1488 \$ 1$. «Se prohíbe a ambos [procuradores y abogados] comprar el pleito, o pactar acerca de unos emolumentos excesivos o sobre una parte reclamada de la cosa litigiosa. Si hicieran eso, el pacto es nulo, y pueden ser multados por el juez. Además, el abogado puede ser suspendido de su oficio o, si es reincidente, eliminado del elenco de abogados por el Obispo que preside el tribunal». La Instrucción Dignitas connubii, repite en el art. 110 el precepto. En el c. 308 establece: «Art. 308. El Obispo Moderador debe velar para que, por el modo de actuar de los ministros del tribunal o por el coste exagerado, los fieles no se vean apartados del ministerio de los tribunales, con grave daño para las almas, cuya salvación debe ser siempre ley suprema en la Iglesia». 
Abogados españoles y las Vicarías Judiciales (reglamento de los Tribunales Eclesiásticos) ${ }^{41}$, que debe ser respetada.

\section{El ObJETIVO DEL PROCESO CANÓNICO DE NULIDAD Y LA CONTRIBUCIÓN DEL ABOGADO}

\subsection{Verdad del matrimonio e interés de parte}

Se plantea aquí el tema de la verdad del matrimonio canónico, en su doble modulación doctrinal o teórica e histórica o fáctica.

El propósito del Derecho y de quienes están a su servicio no es el de encontrar un punto de encuentro entre las partes o una salida satisfactoria. Está en juego y hay que procurar la verdad del matrimonio que coincide, aunque no lo parezca a veces, con el bien de ambos cónyuges y de toda la comunidad. «Deseo recordar, no sólo a quienes forman parte de la Iglesia de Cristo Señor, sino también a todas las personas interesadas en el verdadero progreso humano, la gravedad y el carácter insustituible de algunos principios, que son fundamentales para la convivencia humana, y mucho más para la salvaguardia de la dignidad de todas las personas» ${ }^{42}$.

Ello no es incompatible con el interés de las partes y la defensa de su postura. La Dignitas connubii estatuye que: «El abogado y el procurador tienen la obligación de defender según su función propia los derechos de la parte y de guardar secreto de oficio» (art. $104 \$ 1$ ). La verdad de que hablamos se sitúa en un plano más elevado (institucional), tutelado por el juez (tercero imparcial), que, teniendo en cuenta las pretensiones en liza, las coteja con los hechos y con lo previsto por la ley, para declarar lo que se cree justo.

El abogado no es ajeno al compromiso con la justicia. «La defensa de los intereses de quienes solicitan sus servicios no puede estar reñida con la más estricta veracidad en todos sus actos e intervenciones, convencidos, como han de estar, de que lo más importante para el bien de las personas y el de la Iglesia es

\footnotetext{
${ }^{41}$ Dice la Instrucción Dignitas connubii que: $\ll \$ 1$. El Obispo diocesano para el tribunal diocesano, y el grupo de Obispos, o el Obispo designado por ellos, para el tribunal interdiocesano, ha de dictar normas: $2^{\circ}$ sobre los honorarios de los procuradores, abogados, peritos e intérpretes, así como sobre la indemnización de testigos» (art. 303). Además, C. M. Morán Bustos, Criterios de actuación..., cit., 111-112.

$42 \mathrm{El}$ amor auténtico es el núcleo que sostiene la unidad e indisolubilidad del vínculo. Discurso de Juan Pablo II al Tribunal de la Rota Romana de 1999, n. 2 (https://w2.vatican.va/content/johnpaul-ii/es/speeches/1999/january/documents/hf_jp-ii_spe_19990121_rota-romana.html).
} 
que se haga justicia, no que venza el propio cliente» ${ }^{43}$. A esto se refiere el c. 1611: «La sentencia debe: 1 . dirimir la controversia discutida ante el tribunal, dando a cada duda la respuesta conveniente». En el mismo cuerpo legal se establecen medidas disciplinares para que, quienes intervienen en el proceso, se atengan a su fin natural de buscar la verdad e impartir justicia ${ }^{44}$. El c. 1399 determina genéricamente que: «Aparte de los casos establecidos en ésta u otras leyes, la infracción externa de una ley divina o canónica sólo puede ser castigada con una pena ciertamente justa cuando así lo requiere la especial gravedad de la infracción y urge la necesidad de prevenir o de reparar escándalos».

Concretamente, se refieren al abogado los cánones: 1488, donde se les prohíbe comprar el pleito, y 1490, prohibición de prevaricar de su oficio. El c. 1593 manda al juez que vele por el normal desarrollo del proceso y evite dilaciones indebidas ${ }^{45}$.

Aspectos destacados en su prosecución de la verdad son, para el abogado: tratar de convalidar el matrimonio y restablecer la convivencia conyugal ${ }^{46}$; conformarse con el juez natural del caso $^{47}$; comprometerse con un relato completo y exacto de los hechos, y con que la deposición de los testigos propuestos se atenga a la misma filosofía. Es también obligación suya facilitar un buen peritaje, cuando se necesite.

Sobre la responsabilidad de los operadores jurídico-canónicos, versó el Discurso de Pablo VI a la Rota Romana, de 11 de enero de $1965^{48}$. El compromiso se extendía a los antecedentes del proceso, para no alterar ni admitir manipulaciones en la realidad jurídica del caso, «con motivi infondati, prove inconcludenti, testimoni subornati, documenti contraffatti o manipolati». A la hora de admitir o rechazar una demanda, debe actuar un agudo sentido de la

43 M. A. Sánchez Gómez, Verdad, equidad y justicia en las causas matrimoniales, en C. GuZMán PÉREZ (coord.), XX Jornadas de la Asociación española de canonistas. Sacramentos-cuestiones matrimoniales, Universidad Pontificia de Salamanca, 2001, 259. Además, P. Ma Reyes VizCAíNO, El proceso canónico como búsqueda de la verdad, en http://www.iuscanonicum.org, 8 enero 2009.

44 Cánones 1389, 1391, 1457, 1488 y 1489.

45 C. $1593 \$ 1$. «Si el demandado comparece después en el juicio o responde antes de la definición de la causa, puede aducir conclusiones y pruebas, quedando en pie lo que prescribe el c. 1600; pero ha de procurar el juez que no se prolongue intencionalmente el juicio con largas e innecesarias demoras».

${ }^{46}$ Directorio de la Pastoral Familiar para la Iglesia en España, n. 213, en relación con el c. 1676.

$47 \$ 2$. «Del mismo modo pueden ser castigados los abogados y procuradores que, con fraude de ley, sustraen causas a los tribunales competentes para que sean sentenciadas por otros de modo más favorable».

48 https://w2.vatican.va/content/paul-vi/it/speeches/1965/documents/hf_p-vi_spe_19650111_sacra-rota.pdf. Además, C. M. Morán Bustos, Criterios de actuación..., cit., 37-39. 
justicia en el operador jurídico, de modo que se oponga a aquéllas: «destituite di ogni fondamento, o manifestamente basate sul falso, o anche su fatti veri, ma giuridicamente inetti a ottenere l'effetto desiderato». Pero siempre con la flexibilidad que posibilite la equidad ${ }^{49} \mathrm{y}$ un esclarecimiento favorable de los hechos cuestionados. Pablo VI señala que los operadores jurídicos, deben huir del rigorismo excesivo, «che rifiuta una ragionevole fiducia ai ricorrenti, col pericolo di ostacolare chi sta nel suo giusto diritto, con funeste conseguenze per la sua stessa salvezza eterna, quando si tratti di sanare dolorose situazioni morali». Esta mayor sensibilidad al sufrimiento moral parece haber impulsado la última reforma procesal canónica de 2015.

\subsection{Enseñanzas magisteriales sobre el objetivo del proceso} de las demandas de nulidad

Son muchos los textos que insisten en la preocupación por que el proceso descubra la verdad del matrimonio. Extraemos varias de las Alocuciones anuales a la Rota Romana, dada su relevancia, en tanto que: «il più importante atto ordinario di indirizzo della politica giudiziaria del Tribunale Apostolico e conseguentemente di tutti i tribunali locali» ${ }^{50}$. El de la verdad es un asunto recurrente en las alocuciones. Hacemos una selección de Papas y años.

Empezamos por Pío XII y el citado Discurso de 1944, donde insiste en que debe primar la objetividad y la convicción moral del juez sobre los hechos y no su impresión subjetiva ${ }^{51}$. Tras el Discurso de Pablo VI, en 1965, suficientemente comentado, nos fijamos en el citado Discurso al Tribunal de la Rota Romana de 1999. Allí se dice: «os exhorto a dar prioridad, en la solución de los

${ }^{49}$ Sobre este concepto y su naturaleza jurídica: J. Ma DíAz MORENO, La equidad canónica en la aplicación de las normas jurídicas (cc. 221 \$ 2 y 1752; dc, art. 308), II Jornadas de Actualización Canónica. Matrimonio, Vicarías Judiciales Albacete, Ciudad Real, Cuenca, Guadalajara y Toledo, Albacete 2010, 9-38. «La equidad más que a la ley en sí misma y a su rigurosa aplicación, presta atención al caso concreto, a las personas interesadas y examina la oportunidad o no de atenerse a la letra de la ley» (M. A. SÁNCHEZ GómEZ, Verdad, equidad..., cit., 207).

50 M. DEL Pozzo, Nella verità, la giustizia.Considerazioni a margine della prima Allocuzione benedettina alla Rota, Ius Ecclesiae 18/II (2006) 503-523 (http://bibliotecanonica.net/docsaf/btcaff.pdf [consulta: 8 mayo 2016], 1).

51 «Nel processo matrimoniale il fine unico è un giudizio conforme alla verità e al diritto, concernente nel processo di nullità la asserita non esistenza del vincolo coniugale, nel processo informativo de vinculo solvendo la esistenza, o no, dei presupposti necessari per lo scioglimento del vincolo. In altri termini, il fine è l'accertare autorevolmente e il porre in vigore la verità e il diritto ad essa corrispondente, relativamente all'esistenza o alla continuazione di un vincolo matrimoniale». 
casos, a la búsqueda de la verdad, utilizando las formalidades jurídicas solamente como medio para dicho fin» (n. 2). Más tarde, fue Benedicto XVI el que, en el Discurso al Tribunal de la Rota Romana de 2006, afirma que: «El proceso canónico de nulidad del matrimonio constituye esencialmente un instrumento para certificar la verdad sobre el vínculo conyugal. Por consiguiente, su finalidad constitutiva no es complicar inútilmente la vida a los fieles, ni mucho menos fomentar su espíritu contencioso, sino sólo prestar un servicio a la verdad. Por lo demás, la institución del proceso en general no es, de por sí, un medio para satisfacer un interés cualquiera, sino un instrumento cualificado para cumplir el deber de justicia de dar a cada uno lo suyo. El proceso, precisamente en su estructura esencial, es una institución de justicia y de paz. En efecto, el proceso tiene como finalidad la declaración de la verdad por parte de un tercero imparcial, después de haber ofrecido a las partes las mismas oportunidades de aducir argumentaciones y pruebas dentro de un adecuado espacio de discusión. Normalmente, este intercambio de opiniones es necesario para que el juez pueda conocer la verdad y, en consecuencia, decidir la causa según la justicia. Así pues, todo sistema procesal debe tender a garantizar la objetividad, la tempestividad y la eficacia de las decisiones de los jueces ${ }^{52}$. Desde esta perspectiva, las causas de nulidad encuentran, en la estructura jurisdiccional, su acomodo natural. Las aparentes ventajas de un pronunciamiento directo de la autoridad de la Iglesia serían engañosas. Más riesgo crearía aún hacer depender la declaración sobre la validez del matrimonio del ejercicio de la potestad administrativa. No podemos olvidar que en la existencia de la unión conyugal está imbricado el interés público de la Iglesia con bienes jurídicos fundamentales de los contrayentes. Su estudio y la resolución de las dudas que le afecten merecen de un cauce amplio, supervisado por la autoridad ${ }^{53}$.

Por último, El papa Francisco, en su Discurso de 2016, afirmó que: «la Iglesia, a través de vuestro servicio [se dirige a los auditores rotales], se propone declarar la verdad sobre el matrimonio en el caso concreto, para el bien de los fieles ${ }^{54}$. En las referencias aportadas se enfatiza la fidelidad a los hechos y sus consecuencias jurídicas.

${ }^{52} \mathrm{http} / / /$ w2.vatican.va/content/benedict-xvi/es/speeches/2006/january/documents/hf_benxvi_spe_20060128_roman-rota.html.

53 C. J. ERRÁZURIZ M., Licitud moral de la presentación de la demanda de nulidad matrimonial por los esposos, Ius Canonicum 41 (2001) 180-181.

54 https://w2.vatican.va/content/francesco/es/speeches/2016/january/documents/papa-francesco_20160122_anno-giudiziario-rota-romana.html. 
Existe una rica literatura científica sobre la importancia de la verdad, en las causas canónicas. La doctrina no se desentiende del aspecto institucional: «verdad del matrimonio», quizá para compensar la presión a que ciertos sectores someten sus rasgos definitorios. Asimismo, está presente el tratamiento de la vertiente procesal. Trasluce esta preocupación la bibliografía empleada en este artículo. Recientemente el Decano del Tribunal de la Rota de la Nunciatura Apostólica en Madrid, Mons. Morán Bustos, ha dedicado sendas exposiciones a la «Praxis judicial y verdad del matrimonio» ${ }^{55}$ y a los «Retos de la reforma procesal de la nulidad del matrimonio» ${ }^{56}$. En esta última destaca cómo la verdad e indisolubilidad del matrimonio conservan su importancia en la reforma procesal. El Proemio del M.P. Mitis Iudex confirma el propósito de hacer efectiva la tutela de la verdad del vínculo conyugal. Para ello se recurre a la potestad jurisdiccional de la Iglesia, más garantista que la vía administrativa. Asimismo, se mantiene la naturaleza declarativa de los procesos de nulidad y la necesidad de la certeza moral, en Derecho (art. 12 de las Reglas de procedimiento para tratar las causas de nulidad de matrimonio). La certeza moral de lo sentenciado, sobre la validez del matrimonio, excluye que sea improbable, pero no impone que lo contrario sea imposible.

\section{LA RESPONSABILIDAD DEL ABOGADO EN ESTAS CAUSAS}

\subsection{En el momento de introducirlas}

No basta pensar que el ejercicio de un derecho es siempre lícito. La demanda de nulidad tiene una dimensión deontológica ineludible. Es voluntaria y su progreso exige del impulso procesal permanente del interesado (actor). Por eso, activar la demanda merece reflexión. Hay que evitar, salvo excepciones, la sensación de inexorabilidad. Lo mismo cabe predicar sobre el éxito de la pretensión. Es una falsa expectativa. La decisión de acoger la demanda corresponde al tribunal, tras los avatares del proceso ${ }^{57}$. Sistematizamos los asuntos de calado moral que suscita la demanda de nulidad.

\footnotetext{
55 Octubre 2015. Primeras Jornadas de Derecho Matrimonial Canónico en Canarias, después de la reforma del proceso de nulidad (no publicada).

5631 de marzo de 2016. XXXVI Jornadas de Actualidad Canónica de la Asociación Española de Canonistas. La ponencia será publicada en las Actas de dichas Jornadas.

57 C. J. ERRázuRIZ M., Licitud moral..., cit., 171-174 y 182.
} 
Primero, si se duda de la nulidad y no se ve conveniente o posible la convalidación, queda la alternativa de solicitar la separación, permaneciendo el vínculo, o recurrir a la mediación. La mediación tiene la ventaja de restablecer la convivencia dañada por el conflicto. Ambas partes remueven los obstáculos detectados. Afianzan la confianza mutua y refrigeran los circuitos de la comunicación $^{58}$. Ya señalamos que la Iglesia da mucha importancia al matrimonio (a defenderlo o confirmarlo). De entrada, salvar el matrimonio es un bien, sobre todo para los hijos (Amoris Laetitia, 245-246).

Segundo, ante la sospecha de que la nulidad está fundamentada, cabe, como adelantábamos, que la unión se subsane o convalide. Sólo se debería instar la declaración de nulidad subsidiariamente. La posibilidad o conveniencia de convalidar el matrimonio condiciona la legitimación del promotor de justicia, para impugnar el matrimonio (c. $1674 \$ 2^{\circ}$ ). En palabras de Errázuriz: «el valor moral de la convalidación no se basa nunca en razones extrínsecas -como si simplemente se tratara de llenar de contenido una forma que interesa mantener-, sino en el bien de las mismas personas interesadas, para los cuales llegar a casarse, cuando es posible y conveniente, constituye ciertamente algo bueno» ${ }^{59}$. Es verdad que, en el origen de la demanda de nulidad o disolución, está muy frecuentemente el formalizar canónicamente una convivencia more uxorio (sancionada o no, por el matrimonio civil). Lo complejo de detener una dinámica, que tiende a consolidarse, y relanzar otra incierta, permiten que, en este supuesto, el juez y, a fortiori, el abogado, no pongan inconvenientes a aceptar la causa ${ }^{60}$.

Sólo se justifica la demanda de nulidad o formular una solicitud de disolución del vínculo, cuando estén bien fundamentadas y exista la esperanza de un bien mayor. El abogado, una vez verificado «il proprio talento e le conoscenze che il caso richiede (prima di accettarlo)» ${ }^{61}$, se preocupa del requisito, determinante para admitir la demanda a trámite, del fumus boni iuris. La acción requiere de convicción en la nulidad o en su verosimilitud. Sólo así cabe contrarrestar el respeto que cualquier Ordenamiento muestra por lo actuado bajo la formalidad legal (c. $124 \$ 2$ ). Poco importa que el amparo le venga de un contrato, testamento o acto administrativo ${ }^{62}$. Es más, en el caso del matri-

58 J. EsCRIVÁ IVARS, Separación conyugal y mediación, Ius Canonicum 41 (2001) 247-292.

59 C. J. ERrázUriz M., Licitud moral..., cit., 184.

${ }^{60}$ C. 1675 . «El juez, antes de aceptar una causa, debe tener la certeza de que el matrimonio haya fracasado irreparablemente, de manera que sea imposible restablecer la convivencia conyugal».

${ }^{61}$ M. J. ARroba Conde, Deontologia e norme processuali..., cit., 75-78.

62 C. DE Diego-Lora, Criterios morales..., cit., 236-237. 
monio, no estamos ante un acto jurídico cualquiera. La nota de indisolubilidad lo blinda a la libre disposición de las partes. Pero aquélla quedaría burlada por una utilización veleidosa de los capita nullitatis, esto es, al margen de la verdad fáctica de la unión. «La exigencia de verosimilitud comporta que las partes estén animadas por un espíritu de profunda sinceridad» ${ }^{63}$. El afán del abogado por descubrir, aceptar y afirmar legalmente la verdad, le previene de la artificiosidad. Ésta se da cuando construye y patrocina causas carentes de fundamento, mediante fraude o engaño. Su compromiso con la verdad, servida en conciencia, le debe mover en todas las fases del proceso (ver el Discurso a la Rota Romana de 1944).

Sin el apoyo consistente de la demanda, se activarán las previsiones de la Instrucción Dignitas connubii (arts. 120.2 y 121.4). «El presidente puede y debe, cuando el caso lo requiera, disponer que haya una investigación previa sobre la competencia del tribunal y la capacidad legal del actor para actuar en juicio. $\$ 2$. En cambio, sólo puede disponer una investigación previa sobre la sustancia de la causa en orden a admitir la demanda o rechazarla, si ésta parece carecer de todo fundamento, e incluso solamente para valorar si cabe la posibilidad de que durante el proceso aparezca algún fundamento» (art. 120 $\$ 1$ ). La investigación previa judicial trata de salvar la demanda útil ${ }^{64}$. $\ll$ La demanda puede rechazarse solamente: $4^{\circ}$ si del mismo escrito de demanda se deduce con certeza que la petición carece de todo fundamento y que no cabe esperar que del proceso aparezca fundamento alguno (cfr. c. $1505 \$ 2$ )» (art. $121 \S 1$ ).

Miguel Ángel Torres-Dulce, resume, en cuatro puntos, la justificación de una pretensión de nulidad ${ }^{65}$. Éstos son: $\ll 1^{\circ} \mathrm{El}$ fracaso de la convivencia matrimonial; $2^{\circ} \mathrm{La}$ existencia de indicios razonables de nulidad; $3^{\circ} \mathrm{La}$ imposibilidad o rechazo de una convalidación o sanación; $4^{\circ}$ La intención de obtener una resolución judicial justa», que determine si el matrimonio fue o no real.

$\mathrm{El}$ autor citado propone ejemplos de indicios de nulidad: «los antecedentes de desequilibrios psíquicos, no necesariamente patológicos; determinadas circunstancias que imposibilitan la entrega; poner condiciones al consentir; excluir alguno de los bienes del matrimonio, como la prole, la indisolubilidad o

${ }^{63}$ C. J. ERráZuriz M., Licitud moral..., cit., 178.

${ }^{64}$ No confundir con la investigación prejudicial o pastoral del art. 2, introducida, como novedad, en las Reglas de procedimiento para tratar las causas de nulidad de matrimonio del M.P. Mitis Iudex.

${ }^{65}$ La conveniencia de interponer una demanda de nulidad matrimonial, en http://www.iuscanonicum.org. 
la fidelidad; haberse casado por un embarazo prematrimonial o tratarse de personas notablemente irreflexivas o irresponsables para establecer una relación conyugal». El M.P. Mitis Iudex añade otros indicios razonables de nulidad, que abren a un procedimiento «más breve», ante el Obispo (cc. 1683-1687). Para evitar confusiones, hay que recordar que son indicios o situaciones en las que la nulidad puede producirse. Una posibilidad que, tanto en estos casos como en otros similares, no equivalen a la certeza moral de la nulidad. Este grado de convencimiento, por parte del juez, requerirá de una confirmación, por vía probatoria $^{66}$.

Reproducimos los citados motivos: «La falta de fe que puede generar la simulación del consentimiento o el error que determina la voluntad, la brevedad de la convivencia conyugal, el aborto procurado para impedir la procreación, la obstinada permanencia en una relación extra conyugal al momento de las nupcias o en un tiempo inmediatamente sucesivo, la ocultación dolosa de la esterilidad o de una grave enfermedad contagiosa o de hijos nacidos en una relación precedente o de un encarcelamiento, un motivo para casarse totalmente extraño a la vida conyugal o consistente en el embarazo imprevisto de la mujer, la violencia física ejercida para arrancar el consentimiento, la falta de uso de razón comprobada por documentos médicos, etc.» (art. $14 \$ 1$ de las Reglas de procedimiento para tratar las causas de nulidad de matrimonio del citado M.P. Mitis Iudex).

Consecuencia del compromiso con la verdad, por parte del abogado, y de su rectitud de intención al promover la nulidad, es no tergiversar la realidad fáctica o el valor de las pruebas. «Las partes procesales, al solicitar a la Iglesia su intervención, no sólo intentan defender su legítimo interés, sino que a través de los mecanismos procesales intentan averiguar la verdad de su matrimonio» ${ }^{67}$. El contencioso, y las verdades aportadas, configuran la vía dialógica que hace posible conocer la verdad del caso ${ }^{68}$. Además, de descubrirse engaño se retrotraerían las actuaciones consideradas inválidas (cc. 1644 y ss.).

${ }^{66} \mathrm{M}^{\mathrm{a}} \mathrm{D}$. GARCía CeBriá, Las circunstancias y hechos orientativos de la nulidad clara del art. 14 del Motu Proprio Mitis Iudex Dominus Iesus, para abrir el proceso breve ante el Obispo, Revista General de Derecho Canónico y Derecho Eclesiástico del Estado 40 (enero 2016) 8-9.

${ }^{67}$ P. M $\mathrm{M}^{a}$ REYES VIZCAÍNO, Cuestiones morales en torno a la demanda de nulidad matrimonial, en http://www.iuscanonicum.org, y Unum Sint, edición española de la Federación Católica Internacional de Revistas Communio, Nueva Época 10 (otoño 2008) 117-138.

${ }^{68} \mathrm{~V}$. TURCHI, Il proceso canonico di nullità matrimoniale: tra pubblicità e segretezza, en $\mathrm{M}^{\mathrm{a}} \mathrm{L}$. TACELLI - V. Turchi (a cura di), Scritti in onore di Pietro Pellegrino, II. Scritti di diritto canónico ed ecclesiastico, Edizioni Scientifiche Italiane, Napoli 2009, 535-536. 
Para evitar ofuscaciones, es muy útil la figura de asesor que creó la Instrucción Dignitas connubii, en el art. 113 (que puede ser ocupada por un abogado $\left.^{69}\right): \ll \$ 1$. En cada tribunal debe haber un servicio o una persona a los que pueda dirigirse cualquiera, con libertad y fácilmente, para aconsejarse sobre la posibilidad de introducir la causa de nulidad de su matrimonio y sobre el modo de proceder, en la medida en que pudiera haber fundamento». Asimismo, contribuye al esclarecimiento de motivos posibles de nulidad la citada $2^{\mathrm{a}}$ regla de las establecidas en el procedimiento para tratar las causas de nulidad de matrimonio del M.P. Mitis Iudex. Otra ayuda es la investigación prejudicial o pastoral acerca de «los fieles separados o divorciados que dudan sobre la validez del propio matrimonio o están convencidos de su nulidad» (art. 2). A la indagación pueden contribuir tanto los clérigos, cuanto los laicos.

\subsection{Colaboración en el proceso de nulidad}

Aunque la legitimación de las partes, en las causas matrimoniales (c. $1481^{70}$ ), les habilita para actuar en el proceso por sí mismas (autodefensa), es muy recomendable la ayuda técnica del abogado. En España es habitual recurrir a ella cuando se toma la iniciativa de demandar. La Instrucción Dignitas connubii mantiene la opción de la voluntariedad (arts. 101 y ss.). En la anterior disciplina, sí se exigía la asistencia letrada. Se volvió facultativa por un cúmulo de circunstancias. La principal era de tipo económico, pero se apuntaron otras de oportunidad, en el caso de connivencia entre los cónyuges, o técnicas, cuando no era fácil encontrar canonistas peritos. Sin embargo, para articular un contencioso, sigue pareciendo necesaria y beneficiosa la presencia del abogado. Concurren motivos de diverso tipo: primero, técnico, son procesos complejos y especialmente serios; segundo, práctico, para facilitar la permanente disponibilidad y localización de las partes, y, tercero, de igualdad de recursos, entre todos los contendientes. Se suma a ellos una razón de objetividad. El abogado es un filtro u observador ajeno al conflicto que se dilucida ${ }^{71}$.

${ }^{69}$ La incompatibilidad afecta también, de acuerdo a la lógica, al puesto de asesor, ante el juez unipersonal (nuevo c. $1673 \$ 3$ ), y el que prevé, para el «proceso más breve» ante el obispo (c. 1685).

$70 \ll$ 3. En el juicio contencioso, si se trata de menores o de un juicio en el cual entra en juego el bien público, con excepción de las causas matrimoniales, el juez ha de designar de oficio un defensor a la parte que no lo tiene».

${ }^{71}$ Se defiende la obligatoriedad en: J. LlObell, Il patrocinio forense..., cit., 6; y M. LÓPEZ ALARCón, Intervención de abogado..., cit., 460-463 y 471 y ss. 
Lo más frecuente es que se acumulen todas las tareas de patrocinio (representación-procuraduría y defensa-abogado). La aportación del abogado al buen funcionamiento del proceso se concreta en tres aspectos: garantiza la defensa de los intereses de las partes (ius defensionis); ayuda al ministerio judicial, colaborando en la obligación institucional de adecuar la verdad formal a la sustancial (favor veritatis), y agiliza la actividad de las partes y de los jueces en el cumplimiento de su papel en el proceso (economía procesal) ${ }^{72}$. El abogado actúa de puente entre los intereses privados y el cauce jurídico para atenderlos (recurso público). Gracias a sus conocimientos técnicos y conciencia profesional, la relación entre las partes y el tribunal es más fluida. El tamiz más importante lo aporta, bien al considerar la conveniencia de introducir la causa (demandante), o bien a la hora de responder a la acción (demandado). En esta hipótesis, la postura procesal puede ser de signo diverso e incluso cabe la reconvención.

En el proceso «más breve» ante el Obispo se acentúa la responsabilidad del abogado al demandar. Son dos las razones. La primera, que el acto representa la voluntad o aprobación de ambos cónyuges. La segunda, que este escrito de demanda es más completo que el normal (c. 1504). Incorpora elementos extra (c. 1684): $1^{\circ}$ exposición de los hechos que dan cobertura a la pretensión, con las notas de enumeración sucinta, pero integral y clara; $2^{\circ}$ indicación de las pruebas que puedan ser inmediatamente recogidas por el juez; $3^{\circ}$ exhibición, como adjuntos, de los documentos que fundamenten la petición.

Mas la implicación del abogado en el proceso es constante. En la fase instructoria del proceso contencioso ordinario, propone las pruebas y vela por su práctica y resultados (c. 1527). En el momento de la conclusión de la causa, con la publicación, se hace cargo de lo actuado y prepara la fase de discusión, con los mejores argumentos legales, sin olvidar los hipotéticos recursos a que dé lugar la sentencia incongruente («infra vel citra petita», o «ultra vel extra petita»), así como cualquier infracción procesal (c. $1486 \$ 2$ ). Por todo ello, el abogado asume un papel activo en la defensa judicial. Ésta no puede descuidarse, dada la importancia de lo que se cuestiona. Juan Pablo II, en el Discurso ante la Rota Romana (26 enero 1989) así lo subrayó: «el derecho a la defensa tiene una propia importancia particular en las causas para la declaración de nulidad del matrimonio, tanto porque éstas afectan muy profunda e íntimamente a las partes en litigio, o bien porque tratan de la existencia o menos del sagrado vínculo matrimonial».

72 J. LLOBELL, Il patrocinio forense..., cit., 6-7; y M. LÓPEZ ALARCÓN, Intervención de abogado..., cit., 450. 


\section{PRESERVACión de LA PRIVACIDAD Y CONFIDENCIALIDAD DE LOS DATOS}

\subsection{Derechos humanos a la fama e intimidad, su protección canónica}

Por último, abordamos un asunto candente del proceso canónico y en el que la deontología juega un papel importante: el trato considerado de los «datos sensibles» a los que tiene acceso el abogado ${ }^{73}$. Hoy la incisividad y profusión de instrumentos, a través de los cuales se recaba, acumula y difunde información, amenazan permanentemente la intimidad de las personas y su paz interior. El predominio de la vida púbica, a causa de la inflación de la política y del morbo por hacer del otro un espectáculo, eclipsa la vida auténtica, que es prioritariamente privada ${ }^{74}$.

El modo de colaborar en la impartición de justicia, en el foro canónico, esto es, de ofrecerse para tutelar, defender, restituir los derechos de los fieles y velar por el cumplimiento de las obligaciones que les son debidas, sitúa, en un lugar privilegiado, los derechos y deberes fundamentales ${ }^{75}$. La Declaración Conciliar Gaudium et spes (1965) citaba, entre los deberes y derechos universales e inviolables, para una vida verdaderamente humana, el derecho «a la buena fama, al respeto» $\mathrm{y} \ll$ a la protección de la vida privada» $(\mathrm{n} .26 \mathrm{~b})^{76}$. Si se mencionan es por su importancia, en tanto que bienes espirituales. Por su parte, el c. 220 recoge este derecho, con amplitud, y una interpelación a la responsabilidad: «A nadie le es lícito lesionar ilegítimamente la buena fama de que alguien goza, ni violar el derecho de cada persona a proteger su propia intimidad». Sólo se admitiría penetrar en este reducto por razones legítimas o una justa causa, especificada por el Derecho divino o eclesiástico ${ }^{77}$. Existe aquí un tope: «el fuero de la conciencia es absolutamente inviolable», sólo mediando consentimiento del sujeto, se podría acceder a él.

El Derecho establece acciones para erradicar las intromisiones ilegítimas. La protección de la propia intimidad es un derecho y un deber muy relacio-

${ }^{73}$ Con un enfoque iuseclesiasticista: R. Ma RAMíRez NAVALÓn, Problemática en torno a la protección de datos de carácter religioso, en J. OTADUY (coord.), Nuevas situaciones. Nuevas Leyes. Nuevas Respuestas (Actas de las XXIX fornadas de actualidad canónica organizadas por la Asociación Española de Canonistas en Madrid, 15-17 de abril de 2009), Dykinson, Madrid 2010.

${ }_{75}^{74}$ M. García Morente, Ensayo sobre la vida privada, Encuentro, Madrid 2011. Escrito en 1935.

75 M. A. Cremades Romero, Dimensión pastoral..., cit., 17.

76 La Carta Apostólica Octogesima adveniens, 1971 (n. 11), reivindicaba «un mínimo de intimidad», para la vida de familia.

77 D. Cenalmor, Canon 220. Comentario, en Aa.Vv., Comentario exegético al Código de Derecho Canónico, II, Eunsa, Pamplona 1996, 139. 
nado con la fama. En principio, se refiere a la intimidad psicológica y moral del hombre, esto es, a un ámbito específicamente personal (fuero interno o de la conciencia). Sin embargo, puede amparar también a la Iglesia cuando se desborda lo público y notorio, para entrar en la esfera privada de las personas 0 instituciones ${ }^{78}$.

La publicidad no choca frontalmente con el derecho a la privacidad. Sí lo somete a tensión y puede entenderse como excepción, dentro de lo que, en general, es una conducta ilícita. Por este motivo, la divulgación de datos que afectan a la intimidad personal debe canalizarse entre límites y cautelas ${ }^{79}$. Esto restringe, por ejemplo, al acceso al correo o a los mensajes personales. En este sentido, se han incluido, en el c. 1548.2 (y el art. 194.2 de la Dignitas connubii), la exención de la obligación de responder en juicio a clérigos o profesionales sujetos al secreto de oficio y a familiares que teman perjudicar la credibilidad de los más allegados. Correlativos al anterior son el c. $1546 \$ 1$ y el art. 192 de la Dignitas connubii. Citamos este último, una reproducción fiel del c. 1546. Dice así: $₫ 1$. «Nadie está obligado a presentar documentos, aunque sean comunes, que no puedan mostrarse sin peligro de daño, de acuerdo con el art. $194 \$ 2$, n. 3, o sin peligro de violar la obligación de secreto (cfr. c. 1546 $\$ 1)$. $\$ 2$. Sin embargo, si es posible transcribir al menos una parte del documento y mostrarla sin los inconvenientes mencionados, el juez puede mandar que se presente (c. $1546 \$ 2) \gg$.

Scaglia va más lejos e interpreta que, la cláusula general que aparece en el c. 1489 , para sancionar cualquier supuesto de traición del oficio de defensor, incluye aquella «condotta degli Avvocati citati come testimoni, che -quantunque ex c. $1548, \$ 2$, n. $1^{\circ}$, "liberati dal dovere di rispondere" in quanto tenuti al segreto d'ufficio, "anche in ragione del consiglio dato, per quanto riguarda le questioni soggette a questo segreto"- rispondono all'interrogatorio» ${ }^{80}$.

La materia conyugal es de índole privada y debe preservarse de la curiosidad o malevolencia ajena. Lo destacó el Discurso a la Rota Romana de 1989: «la "publicidad" del juicio canónico hacia las partes en litigio, no ataca

78 D. Cenalmor, Canon 220. Comentario, cit., 141.

79 Sin embargo, en el Derecho procesal canónico el secreto es la excepción. V. TuRCHI, Il proceso canonico..., cit., 483-484.

80 S. SCAGLIA, Notazioni per una deontología..., cit., 28. La sanción que prevé el canon es la suspensión de su oficio y una multa u otra pena ajustada (materia criminal). 
su naturaleza reservada respecto a todos los demás». De hecho, hay cautelas procesales, parcialmente explicadas, para que no aflore lo menos relevante o más delicado ${ }^{81}$. Pero en el matrimonio la intimidad se comparte. La defensa de los derechos de quienes en él conviven exige que, en ocasiones, se examine aquel ámbito reservado. El Derecho español ha contemplado la posibilidad de autorizar la exposición de los datos personales, cuando se necesite para ejercitar otros derechos también fundamentales ${ }^{82}$. Ya, en la esfera canónica, pensemos en la peritación, sobre la contraparte, sin su consentimiento. Ello sucederá, cuando el demandado ha sido declarado ausente del proceso, porque se ha desentendido de su desarrollo. En esta hipótesis, puede que sea relevante examinar su capacidad psicológica, en función del motivo de nulidad alegado. Dada su negativa a colaborar, el análisis se limitará a lo actuado y probado $^{83}$.

Chocan aquí el derecho recogido en el c. 220 «a la buena fama» y «al respeto», y el recogido en el c. $221 \$ 1$ : «Compete a los fieles reclamar legítimamente los derechos que tienen en la Iglesia, y defenderlos en el fuero eclesiástico competente conforme a la norma del derecho». La técnica interpretativa de la proporcionalidad -a la que a veces se equipara la «acomodación razonable» anglosajona- nos da la solución para no forzar más de lo necesario su justo encaje. Se trata de ponderar derechos, respetar lo que los hace reconocibles y aplicar límites. Es verdad que los problemas surgen muchas veces respecto a la vocación expansiva o intervencionista de los poderes públicos $^{84}$.

${ }^{81}$ Continúa la alocución: «Es necesario, además, notar que la ley canónica exime del deber de responder en juicio a todos los que están obligados al secreto de oficio, en la que se refiere a los asuntos sometidos a este secreto, y también para quienes temen que de su testimonio les sobrevendrán infamia, vejaciones peligrosas u otros males para sí mismos, para el cónyuge, o para consanguíneos o afines próximos (cfr. c. $1548 \$ 2$ ), y que, también respecto a la producción de documentos en juicio, existe una norma semejante (cfr. c. 1546). No puede pasar desapercibido el hecho, además, de que en las sentencias es suficiente la exposición de las razones de derecho y de hecho sobre las cuales se rige, sin deber mencionar cada uno de los testimonios».

82 C. M. Morán Bustos, Criterios de actuación..., cit., 95-96. Cita la sentencia del Tribunal Supremo de 4 de noviembre de 1996, FJ $7^{\circ}$, para ilustrar su reflexión.

83 J. T. MARTÍN DE AgAR, La pericia super Actas: dificultades, certeza y valor objetivo, Ius Canonicum 53 (2013) 83-97.

${ }^{84} \mathrm{M}^{\mathrm{a}} \mathrm{J}$. ROCA FERNÁNDEZ, Luces y sombras en la argumentación de la jurisprudencia reciente del TEDH sobre el art. 9 del Convenio. Comentario a la ponencia de la Dra. María Elósegui Itxaso, en $M^{a}$ ElóSEGUI ITXASO (coord.), Los principios y la interpretación judicial de los derechos fundamentales. Homenaje a Robert Alexy en su 70 Aniversario, Fundación Manuel Giménez Abad, Zaragoza y Marcial Pons, Zaragoza 2016, 187-205. 


\subsection{La tensión entre publicidad y privacidad en las causas matrimoniales canónicas}

De entrada, proceso es sinónimo de publicidad prioritariamente entre las partes, pero también ante los terceros, como garantía de transparencia. En esto, el Código de 1983 no es muy exigente.

Sobre la publicidad ante las partes, en general: $\ll$ Si una ley particular no dispone otra cosa, mientras se trata la causa ante el tribunal sólo deben estar presentes en el aula aquellos que la ley o el juez determinen que son necesarios para realizar el proceso» $(\text { c. } 1470 \$ 1)^{85}$. «El abogado ejerce una función necesaria que le legitima para intervenir en el proceso. La ley establece la previsión de su nombramiento para el puesto. Puede ser el mandato de su cliente quien lo habilite, para la defensa forense, o la designación del juez cuando estime que una de las partes, que no haya provisto a su nombramiento, no puede carecer de él» ${ }^{86}$. Es importante que el abogado acredite su título, para actuar en el proceso. El c. 1484 dice: «\$1. El procurador y el abogado, antes de iniciar su función, deben presentar su mandato auténtico al tribunal». A partir de aquí, la regla, para el proceso contencioso ordinario, es que al letrado se le admita en el proceso, con un papel activo, y a las partes (por él tuteladas) no ${ }^{87}$.

${ }^{85}$ Su correlato está, para proceso de nulidad canónica, en el art. 86: «Mientras se trata la causa ante el tribunal sólo deben estar presentes en la sala aquellos que la ley o el juez determinen que son necesarios para realizar el proceso (cfr. c. $1470 \$ 1$ )».

${ }^{86}$ C. $1481 \S 1$. «La parte puede designar libremente su abogado y procurador; pero, salvo en los casos indicados en los $\$ \$ 2-3$, puede también demandar y contestar personalmente, a no ser que el juez considere necesaria la ayuda del procurador o del abogado. $\$ 2$. En el juicio penal, el acusado debe tener siempre un abogado, elegido por él mismo o nombrado por el juez. $\$ 3$. En el juicio contencioso, si se trata de menores o de un juicio en el cual entra en juego el bien público, con excepción de las causas matrimoniales, el juez ha de designar de oficio un defensor a la parte que no lo tiene». Esta norma se completa, para la nulidad de matrimonio, con el art. 101 de la Instrucción Dignitas Connubii. «\$ 1. Quedando a salvo el derecho de las partes a defenderse personalmente, el tribunal tiene la obligación de proveer a que ambos cónyuges puedan defender sus derechos con la ayuda de una persona competente, sobre todo si se trata de causas de especial dificultad. $\$$ 2. Si a juicio del presidente la ayuda de un procurador o de un abogado es necesaria y la parte no provee dentro del plazo establecido, debe nombrarlos el mismo presidente, según lo requiera el caso, para que permanezcan en el ejercicio de su función hasta que la parte nombre a otros. \$S 3. Si se concede el patrocinio gratuito, el nombramiento del procurador o del abogado corresponde al mismo presidente del tribunal. $\$ 4$. En todo caso, el nombramiento por decreto de procurador o de abogado debe comunicarse a las partes y al defensor del vínculo».

${ }^{87}$ C. 1559 (proceso contencioso ordinario). Existe laxitud en el proceso oral (del que están excluidas las causas de nulidad matrimonial $e x$ c. 1690). C. 1663: «\$2. Cada parte y su abogado pueden asistir al interrogatorio de las demás y de los testigos y peritos». El proceso «más breve» ante el Obispo, para las nulidades canónicas, mantiene la regla expuesta. Según el c. 1685. «El Vicario judicial, con el mismo decreto con el que determina la fórmula de dudas, nombre el ins- 
La publicidad hace posible el derecho a la defensa ${ }^{88}$ y suscita el celo popular para que se haga justicia. El Código de Derecho canónico de 1983 ha supuesto un avance respecto a la publicidad de la actuación judicial. Vela porque sea conocida de las partes (publicidad interna). En el Código de 1917, el proceso matrimonial se asemejaba más al penal que al contencioso, por lo cual el secreto afectaba a toda la fase instructoria. Sin embargo, entonces existía, con excepciones, una acción popular de nulidad del matrimonio. Su desaparición se ha de considerar un acierto, en orden a la justicia y, en concreto, a la privacidad. Dada la índole personalísima del matrimonio, parecía perturbador que, desde fuera de su núcleo, se pudiese comprometer su evolución. Para los problemas escandalosos, todo queda en manos de una instancia pública, el promotor de justicia ${ }^{89}$.

No existe progreso del Código de 1983, respecto a la apertura del proceso a la opinión pública. A veces, se ha hablado de la democratización de la Iglesia, pero, aunque el acercamiento entre la jerarquía y el pueblo fiel sea deseable ${ }^{90}$, lo normativo aquí es cumplir con la voluntad de Jesucristo, en orden a la estructura eclesial y su fin salvífico. Tal es la responsabilidad de las autoridades legítimas, sin dar pábulo al hipercriticismo ${ }^{91}$.

El vigente c. 1678 , en relación con el c. $1559^{92}$, dispone que: $\ll \$ 1$. El defensor del vínculo, los abogados y también el promotor de justicia si intervie-

tructor y el asesor, y cite para la sesión, que deberá celebrarse conforme el c. 1686, no más allá de treinta días, a todos aquellos que deben participar». El precepto se completa con las Reglas de procedimiento para tratar las causas de nulidad de matrimonio (art. $18 \$ 1$ ) que permite un acceso general de abogados y partes. Por su parte, el citado c. 1686 dispone que: «El instructor, en la medida de lo posible, recoja las pruebas en una sola sesión, y fije el término de quince días para la presentación de las observaciones en favor del vínculo y de las defensas de las partes, si las hay».

${ }^{88}$ C. 1620: «La sentencia adolece de vicio de nulidad insanable si: 7. fue denegado a una de las dos partes el derecho de defensa». Además, art. 270, n. 7 de la Dignitas connubii.

89 C. J. ERrázUriz M., Licitud moral..., cit., 172, nota 5.

90 A. Martínez Blanco, Los derechos fundamentales de los fieles en la Iglesia y su proyección en los ámbitos de la familia y de la enseñanza, Instituto Teológico Franciscano, Murcia 1995, 31-35. Insiste en el derecho de los fieles, ante el ejercicio del poder o potestad de gobierno de la Iglesia, y de cómo ésta debe cohonestarse con la dignidad e iniciativa que le corresponde al fiel.

${ }^{91}$ La Encíclica Redemptor hominis (1979) habla de que: «si es justo que la Iglesia, siguiendo el ejemplo de su Maestro que era "humilde de corazón", esté fundada asimismo en la humildad, que tenga el sentido crítico respecto a todo lo que constituye su carácter y su actividad humana, que sea siempre muy exigente consigo misma, del mismo modo el criticismo debe tener también sus justos límites» (n. 4).

92 «Las partes no pueden asistir al examen de los testigos, a no ser que el juez, sobre todo cuando esté en causa el bien privado, considere que han de ser admitidas. Pueden sin embargo asistir sus abogados o procuradores, a no ser que, por las circunstancias del asunto y de las personas, el juez estime que debe procederse en forma secreta». 
ne en el juicio, tienen derecho: 1. a asistir al examen de las partes, de los testigos y de los peritos, quedando a salvo lo que prescribe el c. 1559; 2. a conocer las actas judiciales, aun cuando no estén publicadas, y a examinar los documentos presentados por las partes. $\$ 2$. Las partes no pueden asistir al examen del que se trata en el $\$ 1,1 \gg^{93}$. El M.P. Mitis Iudex, en sus Reglas de procedimiento para tratar las causas de nulidad de matrimonio, establece, como peculiar del proceso «más breve», que: «Las partes y sus abogados pueden asistir al examen de las otras partes y testigos, a menos que el instructor considere que, por las circunstancias del asunto y de las personas, se deba proceder diversamente» (art. $18 \$ 1)$.

No se pueden admitir pruebas en secreto. Para evitarlo, cuando algo no debe ser difundido, habría que aplicar el art. $161 \$ 1$ de la Dignitas connubii (parte que rehúsa someterse al examen del tribunal, o atenerse a la no comparecencia, prevista en el art. $138 \$ 1$ de la instrucción). Por otro lado, no existe obligación de presentar documentos, cuando se vislumbre un posible daño o deslealtad (art. $192 \$ 1$ de la instrucción). Tampoco los testigos y peritos están obligados a responder, ante la probabilidad, de que lo expuesto les ocasione daños graves a ellos o a sus allegados (art. $194 \$ 2$ de la instrucción).

Dice el art. $157 \$ 2$ de la Dignitas connubii: «No pueden admitirse pruebas bajo secreto, a no ser por causa grave y asegurando su notificación a los abogados de las partes, según lo dispuesto en los arts. 230, 234 (cfr. c. 1598 $\$ 1) \gg$. El art. 190 de la instrucción refuerza la publicidad de la prueba documental exigiendo que sus piezas se depositen en la Cancillería, para su examen por las partes (aquí no es necesario que estén representadas por su patrono). Una prueba obtenida en secreto y no publicada no se podría tener en cuenta en el fallo. Al no ser conocida la prueba, su valor no estaría contrastado, por las partes, y no podría determinar la sentencia. Además, siempre padecería el derecho a la defensa judicial ${ }^{94}$.

\footnotetext{
93 Art. 159 de la Dignitas Connubii: «\$1. El defensor del vínculo y los abogados de las partes tienen derecho: $1^{\circ}$ a asistir al examen de las partes, de los testigos y de los peritos, a no ser que el juez, por lo que se refiere a los abogados, estimara que, por las circunstancias del asunto y de las personas, se debe proceder en secreto; $2^{\circ}$ a conocer las actas judiciales, aun cuando no estén publicadas, y a examinar los documentos presentados por las partes (cfr. cc. $1678 \$ 1 ; 1559)$ ). $\$ 2$. Las partes no pueden asistir al examen del que se trata en el $\$ 1$, n. 1 (c. $1678 \$ 2$ )».

94 E. DE LEÓN REY, Publicación de las actas..., cit., 165.
} 


\subsection{Precauciones procesales y deber de reserva del abogado}

Existen una serie de cautelas en el proceso canónico, que protegen los datos íntimos.

En la fase introductoria, el c. $1676 \$ 1$ parece vencer las reticencias que pudiesen generar, en las causas matrimoniales, el c. $1508 \$ 2$ (retención de la demanda y su no comunicación a la otra parte) ${ }^{95} \mathrm{y}$, con ciertos paliativos, la Dignitas connubii, art. $127 \$ 3^{96}$. El tenor literal del c. $1676 \$ 1$ es éste: «Recibida la demanda, el Vicario judicial, si considera que ésta goza de algún fundamento, la admita y, con decreto adjunto al pie de la misma demanda, ordene que una copia sea notificada al defensor del vínculo y, si la demanda no ha sido firmada por ambas partes, a la parte demandada, dándole el término de quince días para expresar su posición respecto a la demanda».

Sí permanecen, también en los procedimientos de nulidad matrimonial, las cautelas a una publicidad general. En la fase instructoria se restringe el acceso al examen de las partes y a la prueba de testigos y pericial. A esta última sólo pueden tener acceso los abogados (según el comentado c. 1678). En cambio, se admite la consulta de la prueba documental, por todas las partes del proceso (art. 190 de la Dignitas connubii). Respecto a la fase de publicación, de acuerdo al c. $1598 \$ 1{ }^{97}$ pueden mantenerse en secreto algunas actuaciones, siempre que no pongan en riesgo el derecho a la defensa procesal (cosa difícil). Dice el art. 230 de la Dignitas connubii: «Para evitar peligros gravísimos, el juez puede decretar que algún acto no sea manifestado a las partes, teniendo cuidado de que siempre quede a salvo el derecho de defensa (cfr. c. $1598 \$ 1) \gg$.

${ }^{95}$ C. $1508 \$ 1$. «El decreto de citación judicial debe notificarse enseguida al demandado, y al mismo tiempo a aquellos otros que deban comparecer. $\$ 2$. Debe unirse a la citación el escrito de demanda, a no ser que, por motivos graves, el juez considere que éste no debe darse a conocer a la parte antes de que declare en el juicio».

96 Art. $127 \$ 3$. «Debe unirse a la citación el escrito de demanda, a no ser que, por motivos graves, el presidente o el ponente establezcan, mediante decreto motivado, que el escrito no debe darse a conocer a la parte demandada antes de que declare en juicio. En tal caso, sin embargo, es necesario que se notifique a la parte demandada el objeto de la causa y la razón de la demanda aducida por el actor (cfr. c. $1508 \$ 2$ )». Ver V. TuRCHI, Il proceso canonico..., cit., 509-511.

97 «Una vez recibidas las pruebas, el juez, mediante decreto debe permitir, bajo pena de nulidad, que las partes y sus abogados examinen en la cancillería del tribunal las actas que aún no conocen; e incluso se puede entregar copia de las actas a los abogados que la pidan; no obstante, en las causas que afectan al bien público, el juez, para evitar peligros gravísimos, puede decretar que algún acto no sea manifestado a nadie, teniendo cuidado de que siempre quede a salvo el derecho de defensa». 
El derecho a la tutela judicial está previsto en el c. $221 \$ 1$ : «Compete a los fieles reclamar legítimamente los derechos que tienen en la Iglesia y defenderlos con el fuero competente conforme a la norma del derecho». Es un impulso, pro derechos humanos, que empieza a verse desarrollado en las disposiciones procesales, principalmente, c. $1620^{98}$. Se define, en el sentir de la canonística, como: «no sufrir en el seno del proceso una privación o limitación de las posibilidades esenciales de defensa, siempre que tal privación o limitación acarree un perjuicio efectivo y definitivo a los derechos e intereses sustantivos del justiciable no imputable a quien lo alega» ${ }^{99}$.

Complementa lo anterior el art. $235 \$ 1$ de la Dignitas connubii. Es interesante, no tanto por el párr. $1^{\circ}$ : «El juez puede entregar una copia de las actas a los abogados que lo soliciten (cfr. c. $1598 \$ 1$ )», en relación a la publicación de las actas del art. $229 \$ 2$ de la Dignitas connubii ${ }^{100}$, sino sobre todo por el $\$ 2$ : «Los abogados tienen la obligación grave de no entregar copia total o parcial de las actas a otros, ni siquiera a las partes». Esta precaución, incluso frente a las partes, apunta de nuevo a la protección de la intimidad y buena fama de las personas. Éstas se verían desprotegidas, pues, frente a terceros, no existe ninguna medida disciplinar canónica que evite la divulgación ${ }^{101}$. Los mencionados bienes jurídicos no deben ser expuestos sin causa grave.

Precisamente por ello, Scaglia ve coherente, con el sistema canónico, el recurrir al genérico c. 1489 del Código para cubrir la aparente laguna de sanción a los descuidos del abogado que afrenten la intimidad o fama de otros. En el apartado de graves infracciones del deber de secreto o discreción, por parte del abogado, hay que mencionar facilitar copias de las actuaciones, «ad altri, non escluse le Parti ex art. 235, $\$ 2$, D.c.» ${ }^{102}$. Dada la intensidad de la prohibición normativa, la conducta, debe llevar aparejada una sanción que debería ser la fijada en el c. 1489, mediando fraude de ley, previsto por el

98 D. Le Tourneau, Criterios básicos de los discursos de fuan Pablo II a la Rota Romana en los años 1989-1998, Ius Canonicum 38 (1998) 694-696.

99 M. LÓPEZ ALARCÓN, Intervención de abogado..., cit., 465.

100 Art. 229. «\$1. Una vez recibidas las pruebas, antes de la discusión de la causa, el juez debe proceder a la publicación de las actas (cfr. c. $1598 \$ 1$ ). $\$ 2$. La publicación de las actas se hace mediante decreto del juez por el que se concede a las partes y a sus abogados la facultad de examinarlas. $\$ 3$. Por tanto, el juez, mediante ese mismo decreto, debe permitir que las partes y sus abogados examinen en la cancillería del tribunal las actas que aún no conocen, sin perjuicio de lo dispuesto en el art. 230 (cfr. c. $1598 \$ 1$ ) [...]».

101 C. M. Morán Bustos, Criterios de actuación..., cit., 53.

102 S. SCAGLIA, Notazioni per una deontología..., cit., 29. 
art. 110, n. 4 de la Dignitas connubii. Las sanciones que contempla el canon son: la suspensión del ejercicio del oficio, la multa u otra pena acorde a los hechos ${ }^{103}$.

En general, el abogado se compromete a respetar el carácter reservado de lo conocido en el proceso. Según la Instrucción Dignitas connubii: «Siempre que, por la naturaleza de la causa o de las pruebas, la divulgación de las actas o de las pruebas pueda poner en peligro la fama de otros, o dar pie a rencillas, o provocar escándalo u otro inconveniente semejante, el juez puede obligar a guardar secreto bajo un juramento específico o, cuando el caso lo requiera, al menos bajo promesa, a los testigos, a los peritos, a las partes y a sus abogados o procuradores, quedando a salvo los arts. 159, 229-230 (cfr. c. $1455 \$ 3^{104}$ )» (art. $73 \$ 3$ ). Esta previsión se completa con otras disciplinarias ${ }^{105}$. El precepto reproducido no hace otra cosa que reforzar, para una circunstancia especial, el deber del secreto profesional que se exige del abogado, en el art. 104.1 ${ }^{106}$.

Queda la cuestión abierta, en el Derecho español, de cómo hacer compatible la reserva y discreción del abogado, en las causas matrimoniales, con la doctrina, sobre custodia y devolución de la documentación forense, esbozada en la sentencia del Tribunal Supremo, Sala Primera, de 25 de marzo de $1998^{107}$. Recordemos que el Juez puede entregar copias de los autos a los abogados de las partes (art. 235.1 de la Instrucción Dignitas connubii), según el uso forense. Sin embargo, no se le enseñarán a los representados, para evitar el

103 S. SCAGLIA, Notazioni per una deontología..., cit., 29.

104 C. $1455 \ll \$ 1$. Los jueces y ayudantes del tribunal están obligados a guardar secreto de oficio en todo juicio penal, y también en el contencioso cuando puede seguirse algún perjuicio para las partes de la divulgación de algún acto procesal. $\$ 3$. Más aún, siempre que, por la naturaleza de la causa o de las pruebas, pueda ponerse en peligro la fama de otros por la divulgación de las actas o de las pruebas, o se dé pie a rencillas o vaya a provocarse escándalo u otro inconveniente semejante, el juez puede obligar a guardar secreto bajo juramento a los testigos y peritos, así como a las partes y a sus abogados o procuradores».

105 El art. 87 de la Dignitas connubii dispone que: «El juez puede llamar al orden a todos los asistentes al juicio que falten gravemente al respeto y obediencia debidos al tribunal; y a los abogados y procuradores puede incluso suspenderlos del ejercicio de su función en la causa (cfr. c. $1470 \$ 2) \gg$.

106 Art. $104 \$ 1$. «El abogado y el procurador tienen la obligación de defender según su función propia los derechos de la parte y de guardar secreto de oficio».

107 FJ, I.2: «Incursos en el deber de fidelidad se hallan, en relación con el contrato con abogado en el caso de autos, primero, el deber de información adecuada durante la vigencia de la relación contractual y también, con mayor fuerza, en el momento de la extinción y, segundo, el deber de adecuada custodia de todos los documentos, escritos, traslados y actuaciones que se derivan de la relación contractual y actuación profesional y, también con mayor intensidad, en el momento de la extinción, la entrega de toda aquella documentación al cliente». 
mal uso y que se sirvan de la información vertida para fines extraños al proceso canónico, en la esfera del Estado. De esta naturaleza sería promover acciones penales (injurias y calumnias) o civiles (separaciones, nulidades y divorcios), contra el cónyuge o los testigos ${ }^{108}$.

A la vista de ello, la primera precisión que habría que hacer, sobre la responsabilidad del abogado, en este terreno, se refiere a la autonomía de que goza, en nuestro Ordenamiento, la jurisdicción canónica y su funcionamiento (art. I.1 del Acuerdo entre el Estado Español y la Santa Sede, 3 enero 1979 109). Por eso, habría que distinguir lo que es el procedimiento canónico, donde las pautas, antes expuestas, deben seguirse, y la hipotética eficacia civil que, ante los tribunales españoles, pueda tramitarse (art. VI.2 del citado acuerdo y arts. 80 del Código Civil y 778 de la Ley 1/2000, de Enjuiciamiento Civil: Eficacia civil de resoluciones de los tribunales eclesiásticos o de decisiones pontificias sobre matrimonio rato y no consumado). Aquí el abogado debe atenerse a lo que el foro civil demanda. La incidencia de la jurisdicción canónica en el Derecho español (y viceversa) es una cuestión poco estudiada, pero compleja y de interés ${ }^{110}$.

\section{Conclusiones}

Nos ha parecido de interés el detenernos sobre el papel del abogado en los procesos canónicos de nulidad y sus principios deontológicos de actuación. A pesar de la importancia de los asuntos tratados, no siempre se ha profundizado en ellos lo suficiente. El Decano de la Rota de la Nunciatura Apostólica de España se lamentaba del descuido de la deontología en los estudios de Derecho canónico y en las reuniones científico-canónicas ${ }^{111}$. Tampoco existe una

108 C. M. Morán Bustos, Criterios de actuación..., cit., 97.

109 1. «El Estado Español reconoce a la Iglesia católica el derecho de ejercer su misión apostólica y le garantiza el libre y público ejercicio de las actividades que le son propias y en especial las de culto, jurisdicción y magisterio». Entre el Colegio de Abogados de Zaragoza y el Arzobispado de esta Iglesia local se planteó este conflicto, por motivo de la creación de un elenco de patronos estables. Parece que el paso del tiempo rebajó el nivel de tensión inicial. J. L. ACEBAL LujáN, Abogados, procuradores..., cit., 603-604.

110 Se esbozan algunas cuestiones en M. AlENDA SaLINAS, La justicia de tribunales religiosos ante el ordenamiento jurídico español, Revista General de Derecho Procesal 37 (2015) 1-10. Y Mª E. OLMOS, Claves de comprensión de las relaciones entre la justicia secular y la eclesiástica en materia matrimonial. Conflictos y propuestas de solución, en Aa.Vv., Escritos de Derecho Eclesiástico y de Derecho Canónico en honor del profesor Juan Fornés, Comares, Granada 2015.

111 C. M. Morán Bustos, Criterios de actuación..., cit., 108. 
bibliografía española abundante. Además, se han producido cambios recientes que inciden sobre la disciplina legal y la modulación del deber moral.

El punto de partida debe ser la peculiaridad de las causas canónicas. El matrimonio es un estado de vida y un sacramento que afecta directamente al bien público de la Iglesia. La obligación de todos, más aún de los operadores jurídico-canónicos, es la defensa y consolidación del matrimonio. Ahí descansa la razón de ser de la intervención del abogado, cuando se examine la existencia del vínculo. También «es la razón de ser» de su pericia y condición de católico. El abogado no tiene por qué rechazar sistemáticamente que se pretenda la declaración de nulidad, pero ha de proceder con especial sensibilidad y argumentación sólida.

La búsqueda de la verdad en el proceso y la justicia hacia las partes, deben ser el punto de convergencia de los operadores, en el proceso, y su inspiración. Por la verdad (institucional) ha de velar, desde la imparcialidad (super partes), el tribunal u órgano unipersonal ${ }^{112}$.

La interposición de la demanda, o de cómo posicionarse ante ella, tienen un fuerte componente de ética profesional. El proceso «más breve», ante el Obispo, enfatiza el peso procesal de la demanda. Pero la introducción de la causa es sólo el primer paso. El compromiso con el esclarecimiento de los hechos y el rigor en las actuaciones debe presidir también la fase de instrucción, con el recibimiento a prueba, de discusión, con las alegaciones, y de conclusión, con la interposición de recursos. Del proceso en general nos ha parecido importante destacar la publicidad, en conexión con la protección de la intimidad y el derecho a la buena fama. Pensamos en cómo afectan a este derecho y a la tutela judicial el acceso a la demanda, para fijar la cuestión litigiosa, la asistencia a la práctica de las pruebas, para intervenir o verificar su conformidad con la ley, el conocimiento de las actas, medio para obtener un panorama de cuanto de relevante se haya descubierto, y, por último, la lectura de la sentencia, con sus hechos detallados y razonamientos jurídicos.

El derecho humano a la intimidad hoy preocupa particularmente. Por otro lado, afecta directamente a bienes espirituales. Dado que la Iglesia debe ser especialmente diligente en su tutela, se ha redactado, en el Código de 1983 , el c. 220 . Se produce inevitablemente una pugna entre derecho a la privacidad y derecho a una administración de justicia, con todas las garantías.

${ }^{112}$ J. LLOBELL, Il patrocinio forense..., cit., 13-15. 
Éste demanda, con implicación del derecho a la defensa procesal efectiva, transparencia y publicidad. La norma canónica debe ser cuidadosa para que el ejercicio del amparo jurisdiccional no exponga innecesariamente la intimidad de las partes o terceros implicados, vgr., los testigos o peritos, con daño de su dignidad. Asimismo, tratará de prevenir riesgos, para la Justicia eclesial, por hipotéticas reclamaciones, en favor del honor, ante la jurisdicción civil. 


\section{Bibliografía}

ACEBAl Luján, J. L., Abogados, procuradores y patronos ante los tribunales eclesiásticos españoles, en AA.Vv., Curso de Derecho matrimonial y procesal canónico para profesionales del foro, X, Universidad Pontificia de Salamanca, Salamanca 1992, 576 y ss.

Alenda Salinas, M., La justicia de tribunales religiosos ante el ordenamiento jurídico español, Revista General de Derecho Procesal 37 (2015) en http://www. iustel.com.

Arroba Conde, M. J., Deontologia e norme processuali, en Aa.Vv., Deontologia degli operatori di tribunali ecclesiastici, Libreria Editrice Vaticana, Città del Vaticano 2011 (http://www.pul.it/wp-content/uploads/2011/10/MaterialeDidattico-per-il-Tema-26.pdf).

—, Deontología forense canónica, en AA.Vv., Curso de Derecho matrimonial y procesal canónico para profesionales del foro, vol. 19, Universidad Pontificia de Salamanca, Salamanca 2009.

BIANCHI, P., Lidentità dei ruoli nella deontologia forense della Chiesa (testo provvisorio), Pontificia Università della Santa Croce, Programma di formazione permanente per operatori dei tribunali ecclesiastici, V Corso di aggiornamento in diritto matrimoniale e processuale canonico, 19 settembre 2013 (http: //www.pusc.it/sites/default/files/can/cagg13/doc/130919_Bianchi.pdf).

Cenalmor, D., Canon 220. Comentario, en Aa.Vv., Comentario exegético al Código de Derecho Canónico, II, Eunsa, Pamplona 1996, 139.

Сомотті, G., L'esercizio della professione nel foro civile da parte dell'avvocato ecclesiastico. Aspetti deontologici e dovere della coerenza, Quaderni di diritto ecclesiale XXIII/1 (2010) 82-84.

Cremades Romero, M. A., Dimensión pastoral de la administración de justicia en la Iglesia (separata), Clausura del Curso de Actualización Canónica para Abogados 2003-2004, Tribunal Eclesiástico, Diócesis de Albacete (22 de junio de 2004).

De Diego-Lora, C., Criterios morales de la actuación de abogados y peritos en las causas matrimoniales, Ius Canonicum 41 (2001) 233-246 (http://dadun.unav. edu/bitstream/10171/3674/1/81-08.MoralDiego-Lora.pdf).

De León Rey, E., Publicación de las actas, privacidad de los hechos y pruebas secretas (c. 1958.1 CIC 83 / art. 230 DC), en AA.Vv., Procesos matrimoniales canónicos, Asociación española de canonistas, Dykinson, Madrid 2014, 161-162. 
Díaz Moreno, J. M $\mathrm{M}^{\mathrm{a}}$, La equidad canónica en la aplicación de las normas jurídicas (cc. 221 S 2 y 1752; dc, art. 308), II Jornadas de Actualización Canónica, Matrimonio, Vicarías Judiciales Albacete, Ciudad Real, Cuenca, Guadalajara y Toledo, Albacete 2010, 9-38.

ERrÁzuriz M., C. J., Licitud moral de la presentación de la demanda de nulidad matrimonial por los esposos, Ius Canonicum 41 (2001) 169-189 (http://dadun.unav.edu/bitstream/10171/3672/1/81-06.MoralErrazuriz.pdf).

-, Sul rapporto tra diriito e giustizia: valore e aitualita delia tradizione ciassica e cristiana, Persona y Derecho 40 (1999) (http://hdl.handle.net/10171/13872).

EsCrIvá IVARs, J., Separación conyugal y mediación, Ius Canonicum 41 (2001) 247-292 (http://dadun.unav.edu/bitstream/10171/3675/1/81-09.MoralEscriva.pdf).

García-Calderón GarCía, J. A., La intervención del Abogado en los procesos declarativos de nulidad de matrimonio, en J. Bogarín DíAZ - A. Ma López MEDINA (eds.), Nulidad y disolución del matrimonio (Actas de la I y II Jornadas de Derecho matrimonial canónico de la Universidad de Huelva), Publicaciones de la obra social y cultural CajaSur, Córdoba 2007, 61.

GARCía CEBRIÁ, $M^{a}$ D., Las circunstancias y hechos orientativos de la nulidad clara del art. 14 del Motu Proprio Mitis Iudex Dominus Iesus, para abrir el proceso breve ante el Obispo, Revista General de Derecho Canónico y Derecho Eclesiástico del Estado 40 (enero 2016), en http://www.iustel.com.

García Morente, M., Ensayo sobre la vida privada, Encuentro, Madrid 2011.

GIL Delgado, F., Lo peculiar del procedimiento declarativo de nulidad del matrimonio, en J. Bogarín DíAZ - A. Ma LóPez MEdina (eds.), Nulidad y disolución del matrimonio..., cit., 47-48.

Grocholewski, Z., Aspetti teologici dell'attività giudiziaria della Chiesa, Studi Giuridici, XII, Teologia e Diritto canonico, Città del Vaticano 1987.

Le Tourneau, D., Criterios básicos de los discursos de fuan Pablo II a la Rota Romana en los años 1989-1998, Ius Canonicum 38 (1998) 677-704.

LLOBELL, J., Il patrocinio forense e la «concezione istituzionale» del processo canonico, en A. BonNET - C. Gullo (a cura di), Il processo matrimoniale canonico, $2^{a}$ ed., Città del Vaticano 1994, 439-478 (http://didattica.pusc.it/pluginfile.php/6578/mod_page/content/9/021AVVOC.DOC).

LÓPEZ ALARCón, M., Intervención de abogado y derecho de defensa en el proceso canónico de nulidad matrimonial, Anales de Derecho, Universidad de Murcia 21 (2003) 447-487 (http://revistas.um.es/analesderecho/article/viewFile/57541/ $55421)$. 
MARTí SÁNCHEZ, J. Ma , Matrimonio, tradición religiosa y concordataria, en J. $\mathrm{M}^{\mathrm{a}}$ Martí SÁnchez - M. Moreno Mozos (coords.), Matrimonio religioso y Derecho español concordado, Comares, Granada 2016.

MaRTín de Agar, J. T., La pericia super Actas: dificultades, certeza y valor objetivo, Ius Canonicum 53 (2013) 83-97 (http://hdl.handle.net/10171/41289).

Martínez Blanco, A., Los derechos fundamentales de los fieles en la Iglesia y su proyección en los ámbitos de la familia y de la enseñanza, Instituto Teológico Franciscano, Murcia 1995.

Martínez Martínez, F., El proceso canónico y la verdad, en AA.Vv., Religión, matrimonio y Derecho ante el s. XXI. Estudios en bomenaje al Prof. R. NavarroValls, vol. II, Iustel, Madrid 2013, 2999-3013.

Morán Bustos, C. M., Criterios de actuación de los miembros del tribunal y los abogados en el desarrollo del proceso de nulidad, en AA.Vv., Procesos matrimoniales canónicos..., cit., 25-114.

Olmos, $\mathrm{M}^{\mathrm{a}}$ E., Claves de comprensión de las relaciones entre la justicia secular y la eclesiástica en materia matrimonial. Conflictos y propuestas de solución, en AA.Vv., Escritos de Derecho Eclesiástico y de Derecho Canónico en honor del profesor Juan Fornés, Comares, Granada 2015.

Pozzo, M. DEL, Nella verità, la giustizia.Considerazioni a margine della prima Allocuzione benedettina alla Rota, Ius Ecclesiae 18/II (2006) 503-523.

Ramírez Navalón, R. $M^{a}$, Problemática en torno a la protección de datos de carácter religioso, en J. OTADUY (coord.), Nuevas situaciones. Nuevas Leyes. Nuevas Respuestas (Actas de las XXIX Jornadas de actualidad canónica organizadas por la Asociación Española de Canonistas en Madrid, 15-17 de abril de 2009), Dykinson, Madrid 2010.

REYEs VizCAÍNO, P. $\mathrm{M}^{\mathrm{a}}$, Cuestiones morales en torno a la demanda de nulidad matrimonial (http://www.iuscanonicum.org), y Unum Sint, edición española de la Federación Católica Internacional de Revistas Communio, Nueva Época 10 (otoño 2008) 117-138.

-, El proceso canónico como búsqueda de la verdad (http://www.iuscanonicum. org/index.php/derecho-procesal/el-proceso-canonico-en-general/196-elproceso-canonico-como-busqueda-de-la-verdad.html), 8 enero 2009.

RoCa FERNÁNDEZ, $M^{a} \mathrm{~J}$., Luces y sombras en la argumentación de la jurisprudencia reciente del TEDH sobre el art. 9 del Convenio. Comentario a la ponencia de la Dra. María Elósegui Itxaso, en $M^{a}$ Elósegui ITXASO (coord.), Los principios y la interpretación judicial de los derechos fundamentales. Homenaje a Robert Alexy en su 70 Aniversario, Fundación Manuel Giménez Abad, Marcial Pons, Zaragoza 2016, 187-205. 
SÁNCHEZ GÓMEZ, M. A., Verdad, equidad y justicia en las causas matrimoniales, en C. GúZMAN PÉREZ (coord.), XX Jornadas de la Asociación española de canonistas. Sacramentos-cuestiones matrimoniales, Universidad Pontificia de Salamanca, Salamanca 2001.

SATORRAS FIORETTI, R. Ma , La objeción de conciencia jurisdiccional a participar en causas de divorcio, en J. Bogarín DíAZ - A. Ma LóPEZ MEDINA (eds.), Nulidad y disolución del matrimonio..., cit., 107-110, y La Toga 136 (2002) 30-31.

SCAGLIA, S., Notazioni per una deontologia sistematica dell'Avvocato canonista (http://bibliotecanonica.net/docsao/btcaod.pdf).

Torres-Dulce, M. Á., La conveniencia de interponer una demanda de nulidad matrimonial (http://www.iuscanonicum.org).

TURCHI, V., Il proceso canonico di nullità matrimoniale: tra pubblicità e segretezza, en $M^{a}$ L. TACELli - V. TurChI (a cura di), Scritti in onore di Pietro Pellegrino, II. Scritti di diritto canónico ed ecclesiastico, Edizioni Scientifiche Italiane, Napoli 2009 (c. 1684). 